\title{
Engelli Çocuk Sahibi Kadınların Yaşadıkları Güçlüklerin İncelenmesi*
}

\author{
Abdulkadir YÜKSEL ${ }^{\dagger}$
}

Yücel UYANIK**

Geliş Tarihi (Received): 20.09.2021 - Kabul Tarihi (Accepted): 25.10.2021

\section{$\ddot{\mathbf{O} z}$}

$\mathrm{Bu}$ araştırmanın amacı, engelli çocuk sahibi kadınların yaşadıkları güçlük düzeylerini incelemek ve demografik özellikler ile yaşanılan güçlük düzeyleri arasındaki ilişkiyi tespit etmektir. Araştırma, nicel araştırma yöntemlerinden tarama modeline göre tasarlanmıştır. Araştırmada veri toplamak amacıyla "Engelli Çocuk Sahibi Kadınların Yaşadıkları Güçlükleri Belirleme Ölçeği” kullanılmıştır. Araştırma Türkiye'de İç Anadolu bölgesinde bulunan bir ilde basit seçkisiz örneklem seçimi yöntemiyle 392 engelli çocuk sahibi kadın ile yürütülmüştür. Araştırmadan elde edilen verilerinin analizinde SPSS (Statistical Package for the Social Sciences) programı kullanılmıştır ve bulgular tablolar eşliğinde sunulmuştur. Araştırma sonucunda engelli çocuk sahibi kadınların yüksek düzeyde güçlük yaşadıkları ve güçlüklerin yoğunluk sırasına göre; duygusal, ekonomik, fiziksel ve sosyal boyutta olduğu görülmüştür. Yaşanılan güçlük düzeyinin ve boyutlarının yaş, eğitim, çalışma durumu, gelir seviyesi, sosyal güvenlik durumu, engelli çocuğun yaşı ve tıbbi tanısı gibi bazı demografik özelliklere göre anlamlı şekilde farklılaştı̆̆ sonucuna ulaşılmıştır.

Anahtar Kelimeler: Engelli, engelli çocuk sahibi kadın, bakım yükü, güçlük düzeyi, sosyal politika.

\section{Examining the Difficulties of Women with Disabled Children}

\begin{abstract}
The aim of this research is to examine the level of difficulty experienced by women who have children with disabilities and to determine the relationship between demographic characteristics and the level of difficulty experienced. The research was designed according to the survey model, which is one of the quantitative research methods. In order to collect data in the research, "Scale for Identifying the Difficulties Experienced by Women with Disabled Children" was used. The research was carried out with 392 women with disabled children in a province located in the Central Anatolia region of Turkey, using the simple random sampling method. SPSS (Statistical Package for the Social Sciences) program was used in the analysis of the data obtained from the research and the findings were presented with tables. As a result of the research, women with children with disabilities experienced high levels of difficulties and in order of intensity; emotional, economic, physical and social dimensions. It has been concluded that the level and dimensions of difficulty experienced differ significantly according to some demographic characteristics such as age, education, employment status, income level, social security status, age of the disabled child and medical diagnosis.
\end{abstract}

Keywords: Disabled, women with disabled children, care burden, difficulty level, social policy.

\footnotetext{
* Bu makale Gazi Üniversitesi Sosyal Bilimler Enstitüsü Çalışma Ekonomisi ve Endüstri İlişkileri Ana Bilim Dalında ikinci yazar danışmanlığında birinci yazar tarafından tamamlanan doktora tezinden türetilmiştir.

† Öğr. Gör. Dr., Sivas Cumhuriyet Üniversitesi, Şarkışla Aş̧k Veysel Meslek Yüksekokulu, Yönetim ve Organizasyon abdulkadiryuksel@ cumhuriyet.edu.tr, Orcid No: 0000-0002-7038-1609.

** Prof. Dr., Ankara Hacı Bayram Veli Üniversitesi, İktisadi ve İdari Bilimler Fakültesi, Çalışma Ekonomisi ve Endüstri İlişkileri Bölümü, y.uyanik@hbv.edu.tr, Orcid No: 0000-0002-6424-3672.
} 


\section{Giriș}

Geleneksel aile yapıları incelendiğinde erkeğin dışarda çalışarak evin gelir getiricisi, kadının ise evin içerisinde ev idarecisi konumunda olduğu görülmektedir. Bu geleneksel yapı içerisinde kadın çalışma hayatından uzaklaşarak ücretsiz aile işçisi konumunda hayatına devam etmektedir. Toplumsal cinsiyete dayalı bu iş bölümü kadına çocuk bakımı ve ev işleri yükümlülüğünü iliştirmiş durumdadır. Ailede çocuğun doğduğu andan itibaren birincil sorumluluklarını üstlenen ebeveyn kadındır. Çocuk bakımı kadın üzerinde hem bakım emeği hem de duygusal emek bağlamında güçlükler oluşturmaktadır. Normal gelişim gösteren çocukların bakımlarında yaşanan bu güçlük çocuğun engelli olması halinde kendisini daha yoğun hissettirmektedir. Engellilik bireyin yaşadığı yetersizlik nedeniyle kendisinden beklenen rolleri yerine getirememesi durumudur. Dolayısıyla engelli çocuğun yetersizliğinin giderilmesi ve rehabilite edilmesi noktasında anneye büyük sorumluluklar düşmektedir. Bu durum engelli çocuk sahibi kadının bakım yükünün artmasına sebep olmaktadır.

Alan yazında farklı disiplinlerde engelli çocuk sahibi kadınları/ebeveynleri konu alan ulusal ve uluslararası araştırmalar bulunmaktadır. Porterfield (2002) çalışmasında engelli çocuğun aileye getirdiği ekonomik yükün sonucu annenin çalışma hayatına yönelik durumunu araştırmıştır. Green, Davis, Karshmer, Marsh ve Straight (2005) engelli birey ve ailelerin yaşadıkları hissedilen damgalanmanın sosyal süreçlerini incelemişlerdir. Aysan ve Özben (2007) ele aldıkları çalışmalarında engelli çocuk anne babaların yaşam kaliteleri üzerine araştırma yapmışladır. Yıldırım- Sarı (2007) ise zihinsel engelli çocuğu olan ailelerde aile yüklenmesini konu alan çalışma yürütmüştür. Xiong, Yang, Yu, Hou, Li, Liu, Zhang ve Jiao (2011) ele aldıkları çalışmada otizmli, bedensel engelli ve zihinsel engelli çocuklar yetiştirmenin aileye ekonomik yükünü incelemeyi amaçlamışlardır. Fairthorne, Klerk ve Leonard (2016) engelli çocuk sahibi annelerin yaşamış oldukları güçlüklerin belirlenmesi üzerine çalışmışlardır. Oti- Boadi (2017) zihinsel engelli çocukların annelerinin yaşadıkları deneyimlerini özellikle de zihinsel engelli bir çocuk yetiştirme ile ilgili zorlukları ve başa çıkma stratejilerini incelemişlerdir. Deveci ve Ahmetoğlu (2018) tarafindan yapılan araştırmada zihinsel engelli çocuğu olan ebeveynlerin algıladıkları sosyal destek düzeyi araştırılmıştır. Gobrial (2018) otizm spektrum bozukluğu olan çocuk sahibi annelerin yaşamın erken dönemlerine ilişkin yaşadıkları güçlükleri betimlemiştir. Küçük ve Alemdar (2018) çalışmalarında engelli çocuğu olan annelerin yaşam doyumlarını, genel sağlık durumlarını ve depresyon düzeylerini ve de yaşadıkları sorunların neler olduğunu belirlemeyi amaçlamışlardır. Lee, Matthews ve Park (2018) serebral palsili çocuk sahibi annelerin sağlık durumlarının ve sağlıkla ilgili yaşam kalitelerinin tespit edilmesi üzerine çalışmışlardır. Güler ve Çarpi (2019) 
araştırmalarında engelli çocuk sahibi annelerin mesleki tükenmişliği, iş motivasyonu ve eş tükenmişliğini incelenmiştir. Ören ve Aydın (2020) çalışmalarında engelli çocuğa sahip ebeveynlerin bakım yükü ve depresyon durumlarını belirlemeyi amaçlamışlardır. Bu bağlamda alan yazında engelli çocuk sahibi kadın/ ebeveyn konu üzerine birçok çalışmaya rastlanılmıştır (Busch ve Barry, 2007; Lalvani, 2008; Akandere, Acar ve Baştuğ, 2009; Ghosh ve Parish, 2013; Demirbilek, 2013; Meşe, 2013; Pepperell, Paynter ve Gilmore, 2016; Carlos ve Miller, 2017; Akça ve Özyürek, 2019; Jahan, Araf, Griffiths, Gozal ve Mamun, 2020).

$\mathrm{Bu}$ araştırmasının amacı, engelli çocuk sahibi kadınların yaşadıkları güçlükleri belirlemek ve bu güçlüklerin düzeylerini incelemektir. Bu ana amaç doğrultusunda aşağıda yer alan alt amaçlara yanıt aranmıştır.

- Engelli çocuk sahibi kadınların yaşadıkları güçlükler ne düzeydedir? Engelli çocuk sahibi kadınların;

- Ekonomik, sosyal, duygusal ve fiziksel boyutta yaşadıkları güçlükler ne düzeydedir?

- Engelli çocuk sahibi kadınların yaşadıkları güçlüklerin demografik özelliklerine göre anlamlı bir farklılığı var mıdır? Engelli çocuk sahibi kadınların yaşadıkları güçlüklerin kadının;

- Yaşına göre anlamlı bir farklılık var mıdır?

- Medeni durumuna göre anlamlı bir farkl1lık var mıdır?

- Eğitim düzeyine göre anlamlı bir farklılık var mıdır?

- Çalışma durumuna göre anlamlı bir farklılık var mıdır?

- Gelir düzeyine göre anlamlı bir farklılık var mıdır?

- Sosyal güvenliği olması durumuna göre anlamlı bir farklılık var mıdır?

- Sosyal yardım alma durumuna göre anlamlı bir farklılık var mıdır?

- Engelli çocuğun engelli maaşı alması durumuna göre anlamlı bir farklılık var mıdır?

- Evde bakım aylığı imkânından faydalanma durumuna göre anlamlı bir farklılık var midir?

- Engelli çocuğun yaşına göre anlamlı bir farklılık var mıdır?

- Engelli çocuğun engellilik tanısına göre anlamlı bir farklılık var mıdır?

\section{Yöntem}

Engelli çocuk sahibi kadınların yaşadıkları güçlüklerin incelenmesi amacıyla gerçekleştirilen bu çalışmada nicel araştırma yöntemi tekniklerinden yararlanılmıştır. Nicel araştırmalar, değişkenler arasındaki ilişkileri kanıtlamaya çalışmakta ve araştırmacının 
genelleme yapmasına, tahminlerde bulunmasına ve nedensellik ilişkisini açıklamasına yardımcı olmaktadır (Büyüköztürk, Kılıç Çakmak, Akgün, Karadeniz, Demirel, 2014, s.12). Nicel araştırmalar genellikle bilgi, deney ve gözlem ile aklın kurallarına göre elde edilen genellenebilirliği yüksek, sayısal olarak ifade edilebilen ve üzerinde istatistiksel işlemler yapılabilen araştırma yöntemidir (Sönmez ve Alacapınar, 2011, s.41). Bu araştırmada nicel araştırma yöntemlerinden tarama modeli kullanılmıştır. Tarama modeli; bir konu ya da olaya ilişkin var olan bir durumu olduğu gibi betimlemeyi amaçlayan bir nicel araştırma modelidir (Büyüköztürk ve diğ., 2014, s.177).

\subsection{Evren ve Örneklem}

$\mathrm{Bu}$ araştırmada olasılıklı örnekleme tekniklerinden basit seçkisiz örnekleme tekniği kullanılmıştır. Basit seçkisiz örnekleme; araştırma evrenindeki her bir bireyin örnekleme girme olasılığının eşit ve birbirinden bağımsız olduğu bir örnekleme tekniğidir (Erkuş, 2005, s.84).

Bu araştırma Türkiye'de İç Anadolu bölgesinde bulunan bir ilde yürütülmüştür. İlgili İ'de yaşayan ve araştırmanın öznesi konumunda olan engelli çocuk sahibi kadınların sayısına ulaşabilmek amacıyla engelli çocuk sayısı dikkate alınmıştır. Engelli çocuk sayısı ile engelli çocuk sahibi kadın sayısı eşit kabul edilmiştir ve bu durum araştırma açısından bir sayıltıdır. Bu doğrultuda İl Milli Eğitim Müdürlüğü Rehberlik ve Araştırma Merkezi (RAM) tarafından eğitsel değerlendirme ve tanılaması yapılmış olan ve aktif olarak özel eğitim hizmetlerinden faydalanan çocuk sayısı dikkate alınmıştır. RAM tarafından eğitsel değerlendirilmesi ve tanılaması yapılarak özel eğitim hizmetlerinden faydalanan çocuk sayısından üstün zekâl1/yetenekli çocuk sayısı çıkarılarak engelli çocuk sayısına ulaşılmıştır. Bu doğrultusunda araştırmanın evreni; RAM tarafından eğitsel değerlendirilmesi ve tanılaması yapılan engelli çocuk sayısı olan 3175 çocuğun annesi konumundaki kadınlardır.

Araştırmanın örneklem büyüklüğü belirlenirken; araştırma evrenini temsil eden en büyük örneklem büyüklüğüne Büyüköztürk ve diğg.( 2014, s.96) tarafindan önerilen hesaplama yöntemi kullanılarak ulaşılmıştır. Bu bağlamda araştırmanın evrenini temsil eden örneklem 343 engelli çocuk sahibi kadındır. Bu araştırmada Engelli Çocuk Sahibi Kadınların Yaşadıkları Güçlükleri Belirleme Ölçeği örneklem büyüklüğünün üzerine çıkılarak 392 engelli çocuk sahibi kadının katılımıyla gerçekleştirilmiştir.

\subsection{Veri Toplama Aracı}

Araştırmada veri toplama amacıyla anket tekniği kullanılmıştır. Yüksel (2021) tarafından geliştirilen, geçerlilik ve güvenirliliği sağlanmış olan "Engelli Çocuk Sahibi Kadınların Yaşadıkları Güçlükleri Belirleme Ölçeği” nicel veri toplama aracı olarak 
kullanılmıştır. Dört boyut ve 27 maddeden oluşan ölçeğin geçerlilik ve güvenirlilik (ekonomik güçlük boyutunun 0,913 , sosyal güçlük boyutunun 0,841 , duygusal güçlük boyutunun 0,770 , fiziksel güçlük boyutunun 0,811 ve ölçek toplamının 0,923 Cronbach Alfa değeri saptanmıştır.) kanitları bulunmaktadır.

\subsection{Veri Toplama Süreci}

Araştırmada Engelli Çocuk Sahibi Kadınların Yaşadıkları Güçlükleri Belirleme Ölçeğinin uygulanması ile veri toplama işlemi sağlanmıştır. Demografik bilgi formu ve ölçek maddelerinin yer aldığ 1 form fotokopi yolu ile 600 adet çoğaltılarak araştırma evreninde bulunan engelli çocuk sahibi kadına ulaştırılmıştır. Engelli çocuk sahibi kadınlardan dönütü sağlanan 477 form analize dâhil edilmiştir. Demografik bilgi formu sorularından ve ölçek maddelerinden cevapsız bırakılan 85 form olduğu tespit edilmiştir ve bu formlar değerlendirme dışına alınmıştır. Bu bağlamda 392 katılımcı üzerinden araştırma gerçekleştirilmiştir.

\subsection{Etik Unsurlar}

Bilimsel araştırmaların tüm süreçlerinde etik değerlerin dikkate alınarak gerekli titizlik ile yürütülmesi gerekmektedir (Erkuş, 2005, s.181) Araştırmanın başlangıcından bitişine kadar tüm etik değerler dikkate alınarak araştırma süreci tamamlanmıştır. Araştırma sürecinde dikkate alınan etik değerlere ilişkin bilgiler aşağıda sıralanmaktadır.

- Ankara Hacı Bayram Veli Üniversitesi Etik Kurul Komisyonu'ndan 11/08/2020 tarihli ve E.21933 sayılı yazısı ile araştırmanın etik değerler taşıdığına ilişkin etik kurul onayı alınmıştır.

- Katılımcılara araştırmaya katılmaları için herhangi bir baskı yapılmamış ve herhangi bir hediye, ödül vb. teşvik edici unsur teklif edilmemiştir.

- Katılımcılardan elde edilen ham veriler (demografik bilgi formu ve ölçek formu) üçüncü kişilerle paylaşılmayacak ve korumalı olarak saklanacaktır.

\subsection{Verilerin Analizi}

Araştırmanın verilerinin analizinde betimsel ve anlam çıkarıcı istatistik teknikleri kullanılmıştır. Engelli çocuk sahibi kadınların yaşadıkları güçlüklerin yüzde ve frekans dağılımları incelenmiş ve ölçeğin toplamı ve alt boyutları ile demografik özelliklerin arasındaki anlamlılık analiz edilmiştir. Verilerin analizinde Statistical Package for the Social Sciences 22 (SPSS 22) programı kullanılmıştır. Elde edilen bulgular tablolar ile sunularak açıklanmıştır.

Engelli çocuk sahibi kadınların karşılaştıkları güçlükleri ve bu güçlüklerin düzeyini belirlemek için frekans, yüzde ve aritmetik ortalama değerleri hesaplanmıştır. Ölçek 
maddelerine ilişkin yanıtlar "kesinlikle katılmıyorum=1", "katılmıyorum=2", "kararsızım=3", "katılıyorum=4", "kesinlikle katılıyorum=5" şeklinde kodlanmıştır. Ölçek maddelerine yönelik verilen yanıtları yorumlayabilmek için $5-1=4,4 / 5=0,80$ formülü yardımıyla aralık değerleri hesaplanmıştır. Belirlenen bu aralık değerleri; “1-1,79 arası” çok düşük güçlük düzeyi, “1,802,59 arası” düşük güçlük düzeyi, “2,60-3,39 arası” orta güçlük düzeyi, “3,40-4,19 arası” yüksek güçlük düzeyi ve “4,20-5,00 arası” çok yüksek güçlük düzeyi olarak yorumlanmıştır. Örneklem grubunu oluşturan engelli çocuk sahibi kadınların ölçek maddeleri, ölçek alt boyutları ve ölçek toplamı güçlük düzeyleri bu bağlamda analiz edilmiştir.

Ölçeğin toplamı ve alt boyutları ile demografik özelliklerin arasındaki anlamlılık durumunu analiz etmek için Bağımsız Grup T-Testi ve Tek Yönlü Varyans Analizi (ANOVA) yapılmıştır. Verilerin analizinde homojenlik açısından, $t$ testinde homojenliğin gözlemlenmediği analizlerde $t$ testi çıktısının ikinci satırında yer alan veriler dikkate alınmış ve raporlaştırılmıştır (Başol, 2019). Bu araştırmada anlamlı farklılığın hangi gruplar arasında olduğunun ve anlamlı farklılığın yönünün belirlenmesi için Post Hoc testlerinden homojenliğin sağlandığı durumlarda "Scheffe" testi, homojenliğin sağlanmadığı durumlarda ise GamesHowell testi kullanılmıştır. Araştırmadan elde edilen verilerin normal dağglım göstergelerine ilişkin kanıtlar aşağıda yer alan Tablo 1'de gösterilmektedir.

Tablo 1. Engelli Çocuk Sahibi Kadınların Yaşadıkları Güçlükleri Belirleme Ölçeğinin Uygulama Puan İstatistikleri

\begin{tabular}{llllll}
\hline Değerler & Puanlar & & & & \\
\cline { 2 - 6 } & $\begin{array}{l}\text { Ölçek } \\
\text { (Toplam) }\end{array}$ & $\begin{array}{l}\text { Ekonomik } \\
\text { Güçlük } \\
\text { Boyutu }\end{array}$ & $\begin{array}{l}\text { Sosyal } \\
\text { Güçlük } \\
\text { Boyutu }\end{array}$ & $\begin{array}{l}\text { Duygusal } \\
\text { Güçlük } \\
\text { Boyutu }\end{array}$ & $\begin{array}{l}\text { Fiziksel } \\
\text { Güçlük } \\
\text { Boyutu }\end{array}$ \\
\hline N (Say) & 392 & 392 & 392 & 392 & 392 \\
Ortalama & 92,57 & 36,01 & 16,66 & 24,50 & 15,39 \\
Ortalamanın Standart Hatası & 0,87 & 0,44 & 0,27 & 0,22 & 0,24 \\
Ortanca & 93 & 37 & 17 & 25 & 15 \\
Standart Sapma & 17,29 & 8,89 & 5,49 & 4,42 & 4,80 \\
Varyans & 298,98 & 79,13 & 30,23 & 19,55 & 23,11 \\
Ranj & 93 & 38 & 24 & 22 & 20 \\
Alınan En Yüksek Puan & $134 / 135$ & $50 / 50$ & $30 / 30$ & $30 / 30$ & $25 / 25$ \\
Alınan En Düsük Puan & $41 / 27$ & $12 / 10$ & $6 / 6$ & $8 / 6$ & $5 / 5$ \\
Çarpiklık Değeri & $-0,09$ & $-0,37$ & 0,18 & $-0,96$ & 0,005 \\
Basıklık Değeri & $-0,29$ & $-0,52$ & $-0,54$ & 0,66 & $-0,55$ \\
Cronbach Alpha Güvenirlik Katsayıs1 & 0,891 & 0,891 & 0,802 & 0,716 & 0,764 \\
\hline
\end{tabular}

Tablo 1'de Cronbach Alpha güvenirlik katsayısı incelendiğinde Engelli Çocuk Sahibi Kadınların Yaşadıkları Güçlükleri Belirleme Ölçeğinin uygulamasının iç tutarlık anlamında güvenirliğinin yüksek olduğu görülmektedir. Çarpıklık ve basıklık değer aralıkları hakkında alan yazın da farklı görüşler bulunmaktadır. Bu bağlamda George ve Mallery (2010) çarpıklık ve basıklık aralık değerinin +2 ile -2 arasında olmasını söylerken, Tabachnick ve Fidell (2013) 
bu değerin +1,5 ve -1,5 aralığında ve Hair, Black, Babin, Anderson ve Tatham (2013)'e göre +1 ile -1 arasında olması gerektiği ifade edilmektedir. Bu araştırmada elde edilen çarpıklık ve basıklık değerlerinin yukarıda ifade edilen tüm aralık değerlerine uygun olduğu dolayısıyla verilerin normal dağılım gösterdiği anlaşılmaktadır (Tablo 1).

\section{Bulgular}

Araştırma bulguları, demografik bilgi formu ve Engelli Çocuk Sahibi Kadınların Yaşadıkları Güçlükleri Belirleme Ölçeğinden elde edilen verilerin analizinden oluşmaktadır. Nicel araştırma bulguları; engelli çocuk sahibi kadınların demografik özelliklerine ilişkin bulgular, engelli çocuk sahibi kadınların yaşadıkları güçlük düzeylerine ilişkin bulgular ve engelli çocuk sahibi kadınların yaşadıkları güçlüklerin demografik özelliklerine göre dağılımına ilişkin bulgular şeklinde sunulmaktadır.

\subsection{Engelli Çocuk Sahibi Kadınların Demografik Özelliklerine İlişkin Bulgular}

Engelli çocuk sahibi kadınların demografik özelliklerine ilişkin bulguları; araştırmanın örneklem grubu olan engelli çocuk sahibi kadınların tanımlayıcı özellikleri yüzde (\%) ve frekans (f) değerleri eşliğinde sunulmaktadır. Tablo 2'de engelli çocuk sahibi kadınların demografik özelliklerine ilişkin betimleyici bulgular sunulmaktadır.

Tablo 2. Engelli Çocuk Sahibi Kadınların Demografik Özelliklerine İlişkin Betimleyici Bulgular

\begin{tabular}{|c|c|c|c|}
\hline Değişken & & f & $\%$ \\
\hline \multirow[t]{4}{*}{ Yaş } & 18- 35 Yaş & 131 & 33.4 \\
\hline & 36- 50 Yaş & 244 & 62.2 \\
\hline & 51- 65 Yaş & 17 & 4.3 \\
\hline & Toplam & 392 & 100 \\
\hline \multirow[t]{3}{*}{ Medeni Durum } & Evli & 342 & 87.2 \\
\hline & Bekâr & 50 & 12.8 \\
\hline & Toplam & 392 & 100 \\
\hline \multirow[t]{5}{*}{ Eğitim Durumu } & İlkokul & 92 & 23.2 \\
\hline & Ortaokul & 64 & 16.6 \\
\hline & Lise & 142 & 36.2 \\
\hline & Üniversite & 94 & 24 \\
\hline & Toplam & 392 & 100 \\
\hline \multirow[t]{6}{*}{ Çalışma Durumu } & Kamu Çalışanı & 53 & 13.5 \\
\hline & Özel Sektör & 20 & 5.1 \\
\hline & Serbest & 10 & 2.6 \\
\hline & Emekli & 11 & 2.8 \\
\hline & Çalışmıyor & 298 & 76 \\
\hline & Toplam & 392 & 100 \\
\hline \multirow[t]{6}{*}{ Aylık Gelir } & $0-1000 €$ & 189 & 48.2 \\
\hline & 1001- $2500 €$ & 85 & 21.7 \\
\hline & 2501-3500€ & 44 & 11.2 \\
\hline & 3501- 4500€ & 36 & 9.2 \\
\hline & $4500+$ & 38 & 9.7 \\
\hline & Toplam & 392 & 100 \\
\hline
\end{tabular}


Yukarıdaki Tablo 2'de engelli çocuk sahibi kadınların yaş, medeni durum, eğitim durumu, çalışma durumu ve aylık gelir durumlarına ilişkin yüzde ve frekans değerleri görülmektedir. Aşağıda yer alan Tablo 3'te örneklem kapsamındaki engelli çocuk sahibi kadınların engelli çocuklarının özelliklerine ilişkin betimleyici bulgular yer almaktadır.

Tablo 3. Engelli Çocuk Sahibi Kadınların Engelli Çocuklarının Özelliklerine İlişkin Betimleyici Bulgular

\begin{tabular}{llll}
\hline Değişken & & f & \% \\
\hline Engelli Çocuğun Yaşı & $0-2$ Yaş & 18 & 4.6 \\
& $3-6$ Yaş & 86 & 21.9 \\
& $7-11$ Yaş & 141 & 36 \\
& $12-18$ Yaş & 70 & 17.9 \\
& $18+$ Yaş & 77 & 19.6 \\
\cline { 2 - 4 } & Toplam & $\mathbf{3 9 2}$ & $\mathbf{1 0 0}$ \\
\hline Engelli Çocuğun Cinsiyeti & Kadın & 152 & 38.8 \\
& Erkek & 240 & 61.2 \\
\cline { 2 - 4 } & Toplam & $\mathbf{3 9 2}$ & $\mathbf{1 0 0}$ \\
\hline Engelli Çocuğun Tanısı & Zihinsel Engel & 57 & 14.5 \\
& Bedensel Engel & 92 & 23.5 \\
& Görme Engeli & 16 & 4.1 \\
& İşitme Engeli & 69 & 17.6 \\
& Otizm & 37 & 9.4 \\
& Diğer & 14 & 3.6 \\
& Çoklu Engel & 107 & 27.3 \\
\hline
\end{tabular}

Tablo 3'te örneklem grubunun engelli çocuklarının yaş, cinsiyet ve engellilik tanısına ilişkin betimleyici bulgular yüzde ve frekans değerleri eşliğinde yer almaktadır. Aşağıda Tablo 4'te örneklem grubunun çeşitli özelliklerine ilişkin veriler gösterilmektedir.

Tablo 4. Engelli Çocuk Sahibi Kadınların Çeşitli Özelliklerine İlişkin Betimleyici Bulgular

\begin{tabular}{llll}
\hline Değişken & & $\mathbf{f}$ & $\mathbf{\%}$ \\
\hline Sosyal güvenlik & Evet & 315 & 80.4 \\
& Hayır & 77 & 19.6 \\
\cline { 2 - 4 } & Toplam & $\mathbf{3 9 2}$ & $\mathbf{1 0 0}$ \\
\hline Çocuğun engelli maaşı alma durumu & Evet & 49 & 12.5 \\
& Hayır & 343 & 87.5 \\
\cline { 2 - 4 } & Toplam & $\mathbf{3 9 2}$ & $\mathbf{1 0 0}$ \\
\hline Aileden birisinin engelli bakım aylığı alma durumu & Evet & 184 & 46.9 \\
& Hayır & 208 & 53.1 \\
\cline { 2 - 4 } & Toplam & $\mathbf{3 9 2}$ & $\mathbf{1 0 0}$ \\
\hline Engellilere uygulanan yardım ve hizmetleri yeterli bulma durumu & Evet & 17 & 4.3 \\
& Hayır & 314 & 80.1 \\
\cline { 2 - 4 } & Kararsızım & 61 & 15.6 \\
\hline
\end{tabular}

Tablo 4'te örneklem grubunun sosyal güvenlik durumları, çocuğun engelli maaşı alıp almadığı, aileden birisinin engelli bakım aylığı alma durumu ve engellilere yönelik uygulanan yardım ve hizmetlerin yeterliliği konusuna ilişkin betimleyici bulgular yüzde ve frekans değerleri eşliğinde yer almaktadır. 


\subsection{Engelli Çocuk Sahibi Kadınların Yaşadıkları Güçlük Düzeylerine İlişkin Bulgular}

Engelli çocuk sahibi kadınların yaşadıkları güçlükleri ve bu güçlüklerin düzeylerini belirlemek amacıyla uygulanan Engelli Çocuk Sahibi Kadınların Yaşadıkları Güçlükleri Belirleme Ölçeğinden elde edilen bulgular incelenmiştir. Öncelikle her maddenin değerlendirmesi yapılmış ve engelli çocuk sahibi kadınların ölçek maddelerine katılım durumlarına bakılmıştır. Ölçek maddeleri özelinde yapılan değerlendirme sonrasında ölçeğin boyutları ve geneli dikkate alınarak engelli çocuk sahibi kadınların ölçek boyutları ve ölçek genelinde yaşadıkları güçlük düzeyleri değerlendirilmiştir.

Așağıda Tablo 5’te Engelli Çocuk Sahibi Kadınların Yaşadıkları Güçlüklerin Belirlenmesi Ölçeğinde yer alan ifadeler ve engelli çocuk sahibi kadınların bu ifadelere katılımları frekans (f) ve yüzde (\%) şeklinde sunulmuştur.

Tablo 5. Engelli Çocuk Sahibi Kadınların Yaşadıkları Güçlüklerin Dağılımı

\begin{tabular}{|c|c|c|c|c|c|c|c|c|c|c|c|c|c|c|}
\hline \multirow[t]{2}{*}{ 离 } & \multirow[t]{2}{*}{ 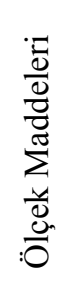 } & \multicolumn{2}{|c|}{ 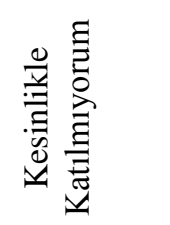 } & \multicolumn{2}{|l|}{ 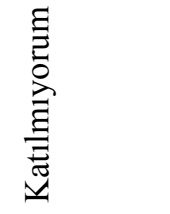 } & \multicolumn{2}{|c|}{ 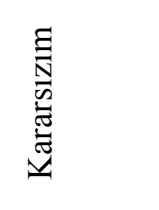 } & \multicolumn{2}{|l|}{ 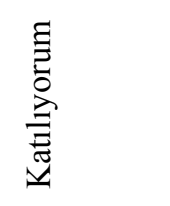 } & \multicolumn{2}{|c|}{ 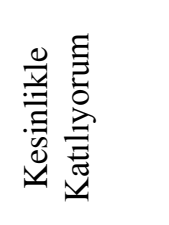 } & \multicolumn{2}{|l|}{ 离 } & \multirow{2}{*}{ 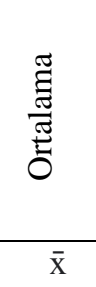 } \\
\hline & & $\mathrm{f}$ & $\%$ & $\mathrm{f}$ & $\%$ & $\mathrm{f}$ & $\%$ & $\mathrm{f}$ & $\%$ & $\mathrm{f}$ & $\%$ & $\mathrm{f}$ & $\%$ & \\
\hline \multirow{10}{*}{ 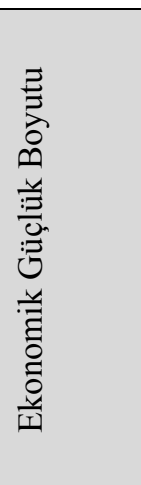 } & 1 & 24 & 6.1 & 46 & 11.7 & 36 & 9.2 & 144 & 36.7 & 142 & 36.2 & 392 & 100 & 3.852 \\
\hline & 2 & 18 & 4.6 & 69 & 17.6 & 36 & 9.2 & 134 & 34.2 & 135 & 34.4 & 392 & 100 & 3.762 \\
\hline & 3 & 27 & 6.9 & 86 & 21.9 & 44 & 11.2 & 120 & 30.6 & 115 & 29.3 & 392 & 100 & 3.535 \\
\hline & 4 & 28 & 7.1 & 59 & 15.1 & 39 & 9.9 & 117 & 29.8 & 149 & 38.0 & 392 & 100 & 3.765 \\
\hline & 5 & 33 & 8.4 & 86 & 21.9 & 65 & 16.6 & 115 & 29.3 & 93 & 23.7 & 392 & 100 & 3.380 \\
\hline & 6 & 27 & 6.9 & 88 & 22.4 & 32 & 8.2 & 121 & 30.9 & 124 & 31.6 & 392 & 100 & 3.579 \\
\hline & 7 & 18 & 4.6 & 91 & 23.2 & 41 & 10.5 & 139 & 35.5 & 103 & 26.3 & 392 & 100 & 3.556 \\
\hline & 8 & 31 & 7.9 & 99 & 25.3 & 71 & 18.1 & 117 & 29.8 & 74 & 18.9 & 392 & 100 & 3.265 \\
\hline & 9 & 40 & 10.2 & 118 & 30.1 & 53 & 13.5 & 110 & 28.1 & 71 & 18.1 & 392 & 100 & 3.137 \\
\hline & 10 & 16 & 4.1 & 19 & 4.8 & 47 & 12.0 & 107 & 27.3 & 203 & 51.8 & 392 & 100 & 4.178 \\
\hline \multirow{5}{*}{ 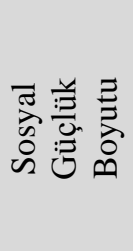 } & 11 & 54 & 13.8 & 82 & 20.9 & 76 & 19.4 & 1.1 & 25.8 & 79 & 20.2 & 392 & 100 & 3.176 \\
\hline & 12 & 157 & 40.1 & 132 & 33.7 & 51 & 13.0 & 34 & 8.7 & 18 & 4.6 & 392 & 100 & 2.040 \\
\hline & 13 & 120 & 30.6 & 92 & 23.5 & 39 & 9.9 & 86 & 21.9 & 55 & 14.0 & 392 & 100 & 2.653 \\
\hline & 14 & 117 & 29.8 & 129 & 32.9 & 71 & 18.1 & 50 & 12.8 & 25 & 6.4 & 392 & 100 & 2.329 \\
\hline & 15 & 57 & 14.5 & 100 & 25.5 & 78 & 19.9 & 82 & 20.9 & 75 & 19.1 & 392 & 100 & 3.045 \\
\hline \multirow{7}{*}{ 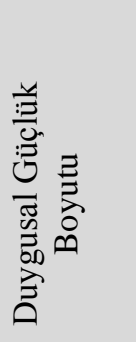 } & 16 & 34 & 8.7 & 72 & 18.4 & 64 & 16.3 & 141 & 36.0 & 81 & 20.7 & 392 & 100 & 3.415 \\
\hline & 17 & 23 & 5.9 & 28 & 7.1 & 12 & 3.1 & 135 & 34.4 & 194 & 49.5 & 392 & 100 & 4.145 \\
\hline & 18 & 11 & 2.8 & 5 & 1.3 & 12 & 3.1 & 85 & 21.7 & 279 & 71.2 & 392 & 100 & 4.571 \\
\hline & 19 & 49 & 12.5 & 80 & 20.4 & 48 & 12.2 & 117 & 29.8 & 98 & 25.0 & 392 & 100 & 3.344 \\
\hline & 20 & 29 & 7.4 & 41 & 10.5 & 19 & 4.8 & 142 & 36.2 & 161 & 41.1 & 392 & 100 & 3.931 \\
\hline & 21 & 13 & 3.3 & 15 & 3.8 & 24 & 6.1 & 77 & 19.6 & 263 & 67.1 & 392 & 100 & 4.433 \\
\hline & 22 & 25 & 6.4 & 32 & 8.2 & 16 & 4.1 & 134 & 34.2 & 185 & 47.2 & 392 & 100 & 4.076 \\
\hline
\end{tabular}


Tablo 5. (Devamı) Engelli Çocuk Sahibi Kadınların Yaşadıkları Güçlüklerin Dağılımı

\begin{tabular}{|c|c|c|c|c|c|c|c|c|c|c|c|c|c|c|}
\hline \multirow[t]{2}{*}{ 点 } & \multirow[t]{2}{*}{ 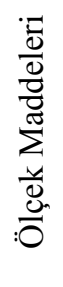 } & \multicolumn{2}{|c|}{ 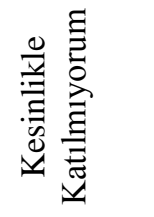 } & \multicolumn{2}{|l|}{ 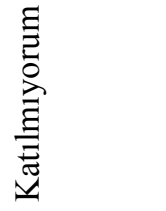 } & \multicolumn{2}{|l|}{ 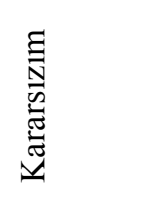 } & \multicolumn{2}{|l|}{ 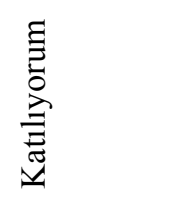 } & \multicolumn{2}{|c|}{ 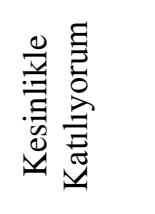 } & \multicolumn{2}{|l|}{$\frac{\Xi}{\tilde{\pi}}$} & \multirow{2}{*}{ 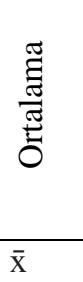 } \\
\hline & & $\mathrm{f}$ & $\%$ & $\mathrm{f}$ & $\%$ & $\mathrm{f}$ & $\%$ & $\mathrm{f}$ & $\%$ & $\mathrm{f}$ & $\%$ & $\mathrm{f}$ & $\%$ & \\
\hline \multirow{5}{*}{ 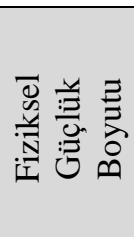 } & 23 & 95 & 24.2 & 118 & 30.1 & 51 & 13.0 & 82 & 20.9 & 46 & 11.7 & 392 & 100 & 2.658 \\
\hline & 24 & 73 & 18.6 & 100 & 25.5 & 39 & 9.9 & 118 & 30.1 & 62 & 15.8 & 392 & 100 & 2.989 \\
\hline & 25 & 46 & 11.7 & 78 & 19.9 & 33 & 8.4 & 138 & 35.2 & 97 & 24.7 & 392 & 100 & 3.413 \\
\hline & 26 & 58 & 14.8 & 99 & 25.3 & 75 & 19.1 & 101 & 25.8 & 59 & 15.1 & 392 & 100 & 3.010 \\
\hline & 27 & 42 & 10.7 & 79 & 20.2 & 56 & 14.3 & 139 & 35.5 & 76 & 19.4 & 392 & 100 & 3.326 \\
\hline
\end{tabular}

Tablo 5 incelendiğinde; ölçeğin ekonomik güçlük boyutunda yer alan maddelere (1, 2 , $3,4,5,6,7,8,9,10$. madde) katılım oranlarının genel olarak yüksek olduğu görülmektedir. Engelli çocuk sahibi kadınlar, ölçeğin 1. maddesi olan "Çocuğumuzun engelli olması aile bütçemizi zorluyor, masraflarımızı artırıyor” ifadesine, \%36,7 katılıyorum ve \%36,2 kesinlikle katılıyorum şeklinde yanıt vermişlerdir. Madde ortalaması incelendiğinde $(\overline{\mathrm{x}}=3,85)$ bu durumun, kadınların yüksek düzeyde yaşadıkları bir güçlük olduğu görülmektedir. Ölçeğin 2 . maddesi olan "Engelli çocuğumun sağlık giderlerini (medikal, ilaç, doktor vb.) karşılamakta zorlanıyorum" ifadesine kadınlar yüksek düzeyde $(\bar{x}=3,76)$ katılım göstermiştir. Örneklem grubunun yarısından fazlasının (\%34,2 katılıyorum ve \%34,4 kesinlikle katılıyorum) sağlık giderleri ile ilgili ekonomik güçlük yaşadığı görülmektedir. Engelli çocuk sahibi kadınların yüksek düzeyde $(\bar{x}=3,53)$ yaşadıkları bir diğer ekonomik güçlük ise engelli çocuğun eğitim harcamalarını karşılamakla ilgilidir. Ölçeğin 3. maddesi olan eğitim harcamaları ile ilgili güçlük yaşama durumuna kadınların \%30,6'ü katılıyorum; \%29,3'ü ise kesinlikle katılıyorum şeklinde yanıt vermiştir. Ölçek 4. maddesi "Çocuğum için bakıcı masraflarını karşılamakta zorlanıyorum/ zorlanırdım." ifadesine katılımcıların \%29,8'i katılmakta ve \%38'i kesinlikle katılmaktadırlar. Madde ortalama puanı incelendiğinde $(\bar{x}=3,76)$ kadınların, engelli çocuklarının bakıcı masraflarını karşılamakla ilgili yüksek düzeyde güçlük yaşadıkları görülmektir. Ölçeğin 5. maddesi olan "Engelli çocuğumun masrafları nedeniyle diğer çocuklarımın ihtiyaçlarını karşılamakta zorlanıyorum” ifadesine örneklem grubunun \%29,3’ü katılıyorum ve \%23,7'si kesinlikle katılıyorum şeklinde yanıt vermiştir. İlgili madde ortalamasına bakıldığında engelli çocuk sahibi kadınların diğer çocuklarının ihtiyaçlarını karşılamakta orta düzeyde güçlük $(\overline{\mathrm{x}}=3,38)$ yaşadıkları anlaşılmaktadır.

Ölçeğin 6. maddesi "Engelli çocuğumun masrafları sosyal harcamalarımızı (tatil, gezi, sinema, konser vb.) kısıtlıyor" ifadesine engelli çocuk sahibi kadınların \%30,9'u katılıyorum, 
\%31,6's1 da kesinlikle katıllyorum şeklinde görüş belirtmektedir. Madde ortalaması incelendiğinde ise yüksek düzeyde $(\bar{x}=3,57)$ güçlük yaşandığı görülmektedir. "Kendi özel ihtiyaçlarımı engelli çocuğumun masrafları nedeniyle karşılamakta zorlanıyorum” şeklindeki ölçeğin 7. maddesine \%35,5 katılıyorum ve \%26,3 kesinlikle katılıyorum düzeyinde katılım gösterilmektedir. İlgili maddenin ortalamasına bakıldığında yüksek düzeyde $(\bar{x}=3,55)$ güçlük ifade ettiği anlaşılmaktadır. Engelli çocuk sahibi kadınların, ölçeğin 8. maddesi olan "Masraflarımızın yüksek olması eşimin ikinci bir işte çalışmasına/ çalışmak istemesine sebep oluyor" ifadesine yönelik güçlük dereceleri orta düzeydedir $(\overline{\mathrm{x}}=3,26)$. Engelli çocuk sahibi kadınların, orta düzeyde güçlük $(\bar{x}=3,13)$ yaşadıkları bir diğer durum ise ölçeğin 9 . maddesinde ifade edilen masrafların yüksek olması nedeniyle akrabaların yardımına ihtiyaç duyma ifadesidir. Ekonomik güçlük boyutunun son maddesi ve ölçeğin 10. maddesi olan "Engelli çocuğum olduğu için devlet tarafından sağlanan destekler yeterli olmuyor" ifadesine \%27,3 katılıyorum ve \%51,8 kesinlikle katılıyorum şeklinde katılım sağlanmaktadır. Engelli çocuk sahibi kadınların bu madde ile ilgili yüksek düzeyde $(\overline{\mathrm{x}}=4,17)$ güçlük yaşadıkları görülmektedir.

Tablo 5'e göre; sosyal güçlük boyutunda yer alan maddelere $(11,12,13,14,15,16$. madde) katılım düzeyleri madde bazında farklılık göstermektedir ve ölçek genel seviyesine göre sosyal güçlük boyutunda genel olarak daha az güçlük yaşandığı görülmektedir. Engelli çocuk sahibi kadınlar engelli çocuklarının çevrelerindeki çocuklar tarafından dışlanması ile ilgili (Madde 11) orta düzeyde $(\bar{x}=3,17)$ güçlük yaşamaktadırlar. Sosyal güçlük boyutunda yer alan ve ölçeğin 12. maddesi olan “Akrabalarım, komşularım, arkadaşlarım çocuğumun engelli olmasından dolayı benimle görüşmek istemiyorlar” ifadesine yönelik katılım düzeyinin düşük $(\bar{x}=2,04)$ olduğu görülmektedir. İlgili maddeye yönelik engelli çocuk sahibi kadınların \%40,1 kesinlikle katılmadıklarını ifade ederken \%33,7'si katılmadıklarını belirtmektedirler. "Engelli çocuğum olduğu için eş-dost ziyaretlerine gitmekten çekiniyorum” şeklinde olan ölçeğin 13. maddesinde yer alan ifadenin engelli çocuk sahibi kadınların orta düzeyde güçlük yaşadıkları bir durum olduğu görülmektedir. Ölçeğin 14. maddesi olan "Çevremdeki insanlar engelli çocuğum ile çocuklarının oynamasını, arkadaş olmasını istemiyor" maddesine \%29,8 kesinlikle katılmıyorum ve \%32,9 düzeyinde katılmıyorum görüşü bulunmaktadır. İlgili maddede geçen ifadenin düşük düzeyde $(\overline{\mathrm{x}}=2,32)$ yaşanılan bir güçlük olduğu söylenebilir. Çocuğunun engelliliğinden dolayı engelli çocuk sahibi kadınların; öğretmen, müdür ve/veya diğer velilerle yaşadıkları sorunlar (Madde 15) orta düzeyde $(\bar{x}=3,04)$ güçlük ifade etmektedir. Sosyal güçlük boyutunda yer alan ve ölçeğin 16. maddesi olan "Engelli çocuğum olduğu için insanların bana acıyarak baktığını düşünüyorum" ifadesine engelli çocuk sahibi kadınların \%36'sı katıldıklarını, \%20,7'si ise kesinlikle katıldıklarını belirtmektedirler. Madde 16'nın 
ortalamasına bakıldığında bu durumun yüksek düzeyde $(\bar{x}=3,41)$ güçlüğe neden olduğu anlaşılmaktadır.

Tablo 5'e bakıldığında engelli çocuk sahibi kadınların duygusal güçlük boyutunda yer alan maddelere $(17,18,19,20,21,22$. madde) katılım düzeylerinin genel olarak yüksek olduğu görülmektedir. Ölçeğin 17. maddesi olan "Çocuğumun engelliliğinden dolayı yaşıtlarından geri olmasına üzülüyorum" ifadesine, engelli çocuk sahibi kadınlar \%34,4 katılıyorum ve $\% 49,5$ kesinlikle katılıyorum şeklinde yanıt vermiştir. Madde ortalaması incelendiğinde yüksek düzeyde $(\bar{x}=4,14)$ güçlük yaşanılan bir durum olduğu görülmektedir. Engelli çocuk sahibi kadınların çok yüksek düzeyde $(\overline{\mathrm{x}}=4,57)$ güçlük yaşadıklarını belirttikleri, ölçeğin 18. maddesi olan "Engelli çocuğumun geleceğini düşündükçe endişeleniyorum” ifadesidir. Engelli çocuk sahibi kadınların ölçeğin tamamına oranla en yüksek düzeyde katılım gösterdikleri maddeye ilişkin yanıtları \%21,7 katılıyorum ve \%71,2 kesinlikle katılıyorum şeklindedir. Engelli çocuk sahibi kadınların ölçeğin 19. maddesi olan "Engelli çocuğum hakkında soru sorulması beni bunaltıyor" ifadesine ilişkin orta düzeyde $(\bar{x}=3,34)$ güçlük yaşadıkları görülmektedir. "Çocuğumun engelli oluşu nedeniyle ağladığım oluyor" şeklindeki ölçeğin 20. maddesine \%36,2 katılıyorum ve \%41,1 kesinlikle katılıyorum şeklinde katılım sağlanmaktadır. Madde ortalaması incelendiğinde ise engelli çocuk sahibi kadınların ilgili ifade de yüksek düzeyde $(\bar{x}=3,93)$ güçlük yaşadıkları anlaşılmaktadır. "Ben öldükten sonra engelli çocuğuma kimin bakacağı konusunda endişe duyuyorum" şeklindeki ölçeğin 21. maddesine; \%19,6 katılıyorum ve \%67,1 kesinlikle katılıyorum şeklinde yanıt verilmiştir. 21 . madde ortalamasına bakıldığında en yükssek düzeyde $(\bar{x}=4,43)$ güçlük ifade ettiği görülmektedir. Duygusal güçlük boyutunda yer alan ve ölçeğin 22. maddesi olan "Çocuğuma engelliliğinden dolayı meraklı gözlerle bakılmasından hoşlanmıyorum” ifadesine \%34,2 katılıyorum ve \%47,2 kesinlikle katıliyorum şeklinde katılım gösterilmektedir ve madde ortalaması yüksek düzeyde $(\overline{\mathrm{x}}=4,07)$ güçlük yaşandığını ifade etmektedir.

Tablo 5'e göre; fiziksel güçlük boyutunda yer alan maddelere (23, 24, 25, 26, 27. madde) katılım düzeyleri madde bazında farklılık göstermektedir. Ölçeğin 23. maddesi olan "Engelli çocuğumun bana bağımlı olmasından sıkıldığım zamanlar oluyor" ifadesinin madde ortalaması incelendiğinde orta düzeyde $(\overline{\mathrm{x}}=2,65)$ güçlüğe işaret ettiği anlaşılmaktadır. Engelli çocuk sahibi kadınlar, çocuklarının bakımı nedeniyle (Madde 24), orta düzeyde $(\bar{x}=2,98)$ güçlük yaşadıklarını ifade etmektedir. Ölçek maddelerinden 25.'si olan "Engelli çocuğumun bakımını tek başıma yapamadığım zamanlar oluyor" ifadesine \%35,2 katılıyorum ve \%24,7 kesinlikle katılıyorum şeklinde katılım sağlanmıştır. Madde ortalamasına bakıldığında ise bu durumun yüksek düzeyde $(\bar{x}=3,41)$ güçlük ifade ettiği görülmektedir. Fiziksel güçlük 
boyutunda yer alan 26. maddenin (Engelli çocuğumdan dolayı diğer çocuklarımın bakımını ihmal ettiğimi düşünüyorum. $)$ ortalaması incelendiğinde orta düzeyde $(\bar{x}=3,01)$ güçlük ifade ettiği görülmektedir. Fiziksel güçlük boyutunda yer alan ve ölçeğin son maddesi olan "Çocuğumun engelinden dolayı genel sağlık durumum bozuldu" ifadesinin madde ortalama değerine bakıldığında orta düzeyde $(\bar{x}=3,32)$ güçlüğe işaret ettiği görülmektedir.

Örneklem grubunu oluşturan engelli çocuk sahibi kadınlar ile Engelli Çocuk Sahibi Kadınların Yaşadıkları Güçlükleri Belirleme Ölçeği uygulaması sonucunda elde edilen veriler betimsel analize tabi tutularak ortalama puanlar ve standart sapmalar hesaplanmıştır. Analiz sonucu ölçeğin; genel güçlük ortalama puanı ve ölçeğin alt boyutları olan ekonomik güçlük, sosyal güçlük, duygusal güçlük ve fiziksel güçlük ortalama puanlarına ilişkin bulgular Tablo 6'da sunulmaktadır.

Tablo 6. Engelli Çocuk Sahibi Kadınların Yaşadıkları Güçlüklerin Düzeyleri

\begin{tabular}{lll}
\hline Ölçek Boyut & Ortalama $(\overline{\mathbf{x}})$ & Standart Sapma $(\mathbf{S S})$ \\
\hline Ekonomik Güçlük & 3.601 & 0.889 \\
Sosyal Güçlük & 2.776 & 0.916 \\
Duygusal Güçlük & 4.083 & 0.736 \\
Fiziksel Güçlük & 3.079 & 0.961 \\
Ölçek Genel Güçlük & 3.428 & 0.640 \\
\hline
\end{tabular}

Engelli çocuk sahibi kadınların yaşadıkları güçlük derecelerini ifade eden ortalama puanlar dikkate alındığında en yoğun güçlüğün duygusal boyutta yaşandığı görülmektedir. Duygusal boyutu ekonomik, fiziksel ve sosyal güçlük boyutları izlemektedir. Ölçeğin genel ortalamasına bakıldığında ise 3.428 ortalama puan -yüksek düzeyde güçlük- şeklinde ifade edilecek seviyede olduğu görülmektedir.

\subsection{Engelli Çocuk Sahibi Kadınların Demografik Özelliklerine Göre Yaşadıkları Güçlüklerin Dağılımlarına İlişkin Bulgular}

Engelli çocuk sahibi kadınların yaşlarına göre yaşadıkları güçlüklerin farklılaşma durumunun incelenmesi amacıyla ANOVA testi yapılmıştır. Ölçeğin toplamı ve alt boyutlarına ilişkin güçlüklerin yaşlarına göre anlamlı bir şekilde farklılaşıp farklılaşmadığını gösteren ANOVA testi sonuçları Tablo 7'de verilmiştir.

Tablo 7. Engelli Çocuk Sahibi Kadınların Yaşadıkları Güçlüklerin Yaşa Göre ANOVA (Tek Yönlü Varyans Analizi) Testi Sonuçları

\begin{tabular}{llllllll}
\hline Boyutlar & $\begin{array}{l}\text { Varyansın } \\
\text { Kaynağı }\end{array}$ & $\begin{array}{l}\text { Kareler } \\
\text { Toplamı }\end{array}$ & sd & $\begin{array}{l}\text { Kareler } \\
\text { Ortalaması }\end{array}$ & $\mathbf{F}$ & $\mathbf{p}$ & $\begin{array}{l}\text { Anlamlı Fark } \\
\text { (Scheffe) }\end{array}$ \\
\hline \multirow{2}{*}{ Ölçek (Toplam) } & Gruplar arası & 1,548 & 2 &, 774 & 1,895 &, 152 & \\
& Gruplar içi & 158,812 & 389 &, 408 & & & \\
& Toplam & 160,359 & 391 & & &, 374 & \\
Ekonomik & Gruplar arası & 1,561 & 2 &, 781 &, 986 &, 374 \\
Güçlük & Gruplar içi & 307,848 & 389 &, 791 & & & \\
\hline
\end{tabular}




\begin{tabular}{|c|c|c|c|c|c|c|c|c|}
\hline Sosyal Güçlük & $\begin{array}{l}\text { Gruplar arası } \\
\text { Gruplar içi } \\
\text { Toplam }\end{array}$ & $\begin{array}{l}6,435 \\
321,895 \\
328,330\end{array}$ & $\begin{array}{l}2 \\
389 \\
391 \\
\end{array}$ & $\begin{array}{l}3,218 \\
, 827\end{array}$ & 3,888 & ,021* & $\begin{array}{l}36-50 \\
35 \text { Yaş }\end{array}$ & Yaş>18- \\
\hline Duygusal Güçlük & $\begin{array}{l}\text { Gruplar arası } \\
\text { Gruplar içi } \\
\text { Toplam }\end{array}$ & $\begin{array}{l}\text {,209 } \\
212,124 \\
212,333\end{array}$ & $\begin{array}{l}2 \\
389 \\
391 \\
\end{array}$ & $\begin{array}{l}, 105 \\
, 545\end{array}$ & ,192 & ,826 & & \\
\hline Fiziksel Güçlük & $\begin{array}{l}\text { Gruplar arası } \\
\text { Gruplar içi } \\
\text { Toplam }\end{array}$ & $\begin{array}{l}12,291 \\
349,226 \\
361,517\end{array}$ & $\begin{array}{l}2 \\
389 \\
391\end{array}$ & $\begin{array}{l}6,145 \\
, 898\end{array}$ & 6,845 & ,001* & $\begin{array}{l}36-50 \\
35 \text { Yaş }\end{array}$ & Yaş>18- \\
\hline
\end{tabular}

*p<.05

Tablo 7 incelendiğinde kadınların yaşadıkları güçlükler yaşlarına göre sosyal güçlük boyutu ve fiziksel güçlük boyutunda anlamlı düzeyde farklılık göstermektedir $(\mathrm{p}<.05) . \mathrm{Bu}$ bulguya göre kadınların yaşlarının yaşadıkları sosyal ve fiziksel güçlükler üzerinde anlamlı bir etkisi vardır. Anlamlı farklılığın hangi gruplar arasında olduğunu belirlemek amacıyla çoklu karşılaştırma testlerinden Scheffe testi yapılmıştır. Sosyal güçlük boyutunda incelendiğinde 18-35 yaş arası kadınlar ile 36-50 yaş arası kadınların yaşadıkları güçlükler anlamlı şekilde farklılaşmaktadır ve bu farklılık 36-50 yaş arası kadınlar lehinedir. Başka bir ifadeyle 36-50 yaş arası kadınların yaşadıkları sosyal güçlük düzeyi 18-35 yaş arası kadınların yaşadıkları sosyal güçlük düzeyinden daha yoğundur. Fiziksel güçlük boyutu incelendiğinde ise 18-35 yaş aras1 kadınlar ile 36-50 yaş arası kadınların yaşadıkları güçlükler arasında 36-50 yaş arası kadınların lehine anlamlı bir fark olduğu görülmektedir. Fiziksel güçlükler bağlamında 36-50 yaş arası kadınların yaşadıkları güçlük düzeyinin 18-35 yaş arası kadınlara göre anlamlı şekilde daha yüksek olduğu anlaşılmaktadır.

Engelli çocuk sahibi kadınların yaşadıkları güçlüklerin medeni durumlarına göre farklılaşma durumlarının incelenmesi amacıyla bağımsız gruplar için T-Testi yapılmıştır. Tablo 8'de ölçeğinin toplamı ve ölçeğin alt boyutlarına ilişkin puanlar sunulmaktadır.

Tablo 8. Engelli Çocuk Sahibi Kadınların Yaşadıkları Güçlük Puanlarının Medeni Duruma Göre Bağımsız Grup T-Testi Sonuçları

\begin{tabular}{|c|c|c|c|c|c|c|}
\hline Boyutlar & Medeni Durum & $\mathbf{N}$ & $\overline{\mathbf{x}}$ & SS & $\mathbf{t}$ & $\mathbf{p}$ \\
\hline \multirow{2}{*}{ Ölçek (Toplam) } & Evli & 342 & 3,4233 & ,63619 & \multirow{2}{*}{,- 431} & \multirow[t]{2}{*}{,667 } \\
\hline & Bekâr & 50 & 3,4652 &, 67415 & & \\
\hline \multirow{2}{*}{ Ekonomik Güçlük } & Evli & 342 & 3,5950 & ,89032 & \multirow[t]{2}{*}{,- 363} & \multirow[t]{2}{*}{,717 } \\
\hline & Bekâr & 50 & 3,6440 & ,89218 & & \\
\hline \multirow{2}{*}{ Sosyal Güçlük } & Evli & 342 & 2,7544 & ,92384 & \multirow[t]{2}{*}{$-1,267$} & \multirow[t]{2}{*}{,206 } \\
\hline & Bekâr & 50 & 2,9300 &, 85654 & & \\
\hline \multirow{2}{*}{ Duygusal Güçlük } & Evli & 342 & 4,0828 & ,73210 & \multirow[t]{2}{*}{,- 064} & \multirow[t]{2}{*}{,949 } \\
\hline & Bekâr & 50 & 4,0900 & ,77680 & & \\
\hline \multirow{2}{*}{ Fiziksel Güçlük } & Evli & 342 & 3,0912 & ,96355 & \multirow[t]{2}{*}{,626 } & \multirow[t]{2}{*}{, 532} \\
\hline & Bekâr & 50 & 3,0000 & ,95362 & & \\
\hline
\end{tabular}

*p<.05

Tablo 8 incelendiğinde medeni durum değişkeni açısından kadınların yaşadıkları güçlüklerin anlamlı düzeyde farklılık göstermediği görülmektedir. Anlamlı farklılık olmamasına rağmen ortalama puanlar incelendiğinde sosyal güçlük boyutunda bekâr kadınların 
evli kadınlara göre daha yüksek puana sahip olduğu anlaşılmaktadır. Başka bir ifade ile bekâr kadınlar evli kadınlara göre daha fazla sosyal güçlükler yaşadıkları anlaşılmaktadır.

Engelli çocuk sahibi kadınların eğitim durumlarına göre yaşadıkları güçlüklerde farklılaşma olup olmadığının incelenmesi amacıyla ANOVA testi yapılmıştır. Ölçeğinin toplamı ve alt boyutlarına ilişkin kadınların yaşadıkları güçlüklerin eğitim durumlarına göre farklılaşıp farklılaşmadığını gösteren ANOVA testi sonuçları Tablo 9'da verilmiştir.

Tablo 9. Engelli Çocuk Sahibi Kadınların Yaşadıkları Güçlüklerin Eğitim Durumuna Göre ANOVA (Tek Yönlü Varyans Analizi) Testi Sonuçları

\begin{tabular}{|c|c|c|c|c|c|c|c|}
\hline Boyutlar & $\begin{array}{l}\text { Varyansın } \\
\text { Kaynağı }\end{array}$ & $\begin{array}{l}\text { Kareler } \\
\text { Toplamı }\end{array}$ & sd & $\begin{array}{l}\text { Kareler } \\
\text { Ortalaması }\end{array}$ & $\mathbf{F}$ & $\mathbf{p}$ & $\begin{array}{l}\text { Anlamlı Fark } \\
\text { (Scheffe) }\end{array}$ \\
\hline \multirow{3}{*}{$\begin{array}{l}\text { Ölçek } \\
\text { (Toplam) }\end{array}$} & Gruplar aras 1 & 1,862 & 3 & ,621 & \multirow[t]{3}{*}{1,520} & \multirow[t]{3}{*}{,209 } & \\
\hline & Gruplar içi & 158,497 & 388 & ,408 & & & \\
\hline & Toplam & 160,359 & 391 & & & & \\
\hline \multirow{3}{*}{$\begin{array}{l}\text { Ekonomik } \\
\text { Güçlük }\end{array}$} & Gruplar aras 1 & 5,306 & 3 & 1,769 & \multirow[t]{3}{*}{2,257} & \multirow[t]{3}{*}{,081 } & \\
\hline & Gruplar içi & 304,103 & 388 & ,784 & & & \\
\hline & Toplam & 309,409 & 391 & & & & \\
\hline \multirow{3}{*}{ Sosyal Güçlük } & Gruplar aras 1 & 2,927 & 3 & ,976 & \multirow[t]{3}{*}{1,163} & \multirow[t]{3}{*}{,323 } & \\
\hline & Gruplar içi & 325,403 & 388 & ,839 & & & \\
\hline & Toplam & 328,330 & 391 & & & & \\
\hline \multirow{3}{*}{$\begin{array}{l}\text { Duygusal } \\
\text { Güçlük }\end{array}$} & Gruplar aras 1 & 4,881 & 3 & 1,627 & \multirow[t]{3}{*}{3,043} & \multirow[t]{3}{*}{,029* } & Üniversite> \\
\hline & Gruplar içi & 207,452 & 388 &, 535 & & & Ortaokul \\
\hline & Toplam & 212,333 & 391 & & & & \\
\hline \multirow{3}{*}{$\begin{array}{l}\text { Fiziksel } \\
\text { Güçlük }\end{array}$} & Gruplar aras 1 & 6,772 & 3 & 2,257 & \multirow[t]{3}{*}{2,469} & \multirow[t]{3}{*}{,062 } & \\
\hline & Gruplar içi & 354,744 & 388 & ,914 & & & \\
\hline & Toplam & 361,517 & 391 & & & & \\
\hline
\end{tabular}

*p<.05

Tablo 9 incelendiğinde engelli çocuk sahibi kadınların yaşadıkları güçlükler eğitim durumuna göre duygusal güçlük boyutunda anlamlı düzeyde farklılık göstermektedir $(\mathrm{p}<.05)$. Anlamlı farklılığın hangi gruplar arasında olduğunu belirlemek amacıyla çoklu karşılaştırma testlerinden Scheffe testi yapılmıştır. Anlamlı farklılığın üniversite mezunları ile ortaokul mezunları arasında olduğu ve anlamlılığın üniversite mezunlarının lehine olduğu anlaşılmaktadır. Bu bağlamda üniversite mezunlarının duygusal güçlük boyutunda yaşadıkları güçlük düzeyinin ortaokul mezunlarına göre daha yüksek düzeyde olduğu söylenebilir.

Engelli çocuk sahibi kadınların yaşadıkları güçlüklerin çalışma durumuna göre farklılaşıp farklılaşmadığını incelemek amacıyla ANOVA testi yapılmıştır. Ölçeğinin toplamı ve alt boyutlarına ilişkin ANOVA sonuçları Tablo 10'da yer almaktadır. 
Tablo 10. Engelli Çocuk Sahibi Kadınların Yaşadıkları Güçlüklerin Çalışma Durumuna Göre ANOVA (Tek Yönlü Varyans Analizi) Testi Sonuçları

\begin{tabular}{|c|c|c|c|c|c|c|c|}
\hline \multirow[t]{2}{*}{ Boyutlar } & \multirow{2}{*}{$\begin{array}{l}\text { Varyansın } \\
\text { Kaynağı }\end{array}$} & \multirow{2}{*}{$\begin{array}{l}\text { Kareler } \\
\text { Toplamı }\end{array}$} & \multirow[t]{2}{*}{ sd } & \multirow{2}{*}{$\begin{array}{l}\text { Kareler } \\
\text { Ortalaması }\end{array}$} & \multirow[t]{2}{*}{$\mathbf{F}$} & \multirow[t]{2}{*}{$\mathbf{p}$} & Anlamlı Fark \\
\hline & & & & & & & $\begin{array}{l}\text { (Scheffe ve Games- } \\
\text { Howell ) }\end{array}$ \\
\hline \multirow{4}{*}{$\begin{array}{l}\text { Ölçek } \\
\text { (Toplam) }\end{array}$} & Gruplar & 3,513 & 4 & ,878 & \multirow[t]{4}{*}{2,167} & \multirow[t]{4}{*}{,072 } & \\
\hline & aras1 & & & & & & \\
\hline & Gruplar içi & 156,846 & 387 & ,405 & & & \\
\hline & Toplam & 160,359 & 391 & & & & \\
\hline \multirow{3}{*}{$\begin{array}{l}\text { Ekonomik } \\
\text { Güçlük }\end{array}$} & $\begin{array}{l}\text { Gruplar } \\
\text { aras1 }\end{array}$ & 10,458 & 4 & 2,615 & \multirow[t]{3}{*}{3,385} & \multirow[t]{3}{*}{, $010 *$} & $\begin{array}{l}\text { Çalışmıyor> } \\
\text { Çalışanı }\end{array}$ \\
\hline & Gruplar içi & 298,951 & 387 & ,772 & & & \\
\hline & Toplam & 309,409 & 391 & & & & \\
\hline \multirow{3}{*}{$\begin{array}{l}\text { Sosyal } \\
\text { Güçlük }\end{array}$} & $\begin{array}{l}\text { Gruplar } \\
\text { aras1 }\end{array}$ & 9,213 & 4 & 2,303 & \multirow[t]{3}{*}{2,793} & \multirow[t]{3}{*}{,026* } & \multirow{3}{*}{$\begin{array}{l}\text { Emekli> Kamu Çalışanı } \\
\text { Emekli> Özel Sektör } \\
\text { Emekli> Çalışmıyor }\end{array}$} \\
\hline & Gruplar içi & 319,117 & 387 & ,825 & & & \\
\hline & Toplam & 328,330 & 391 & & & & \\
\hline \multirow{3}{*}{$\begin{array}{l}\text { Duygusal } \\
\text { Güçlük }\end{array}$} & $\begin{array}{l}\text { Gruplar } \\
\text { aras1 }\end{array}$ & 1,869 & 4 & ,467 & \multirow[t]{3}{*}{859} & \multirow[t]{3}{*}{,489 } & \\
\hline & Gruplar içi & 210,465 & 387 &, 544 & & & \\
\hline & Toplam & 212,333 & 391 & & & & \\
\hline \multirow{3}{*}{$\begin{array}{l}\text { Fiziksel } \\
\text { Güçlük }\end{array}$} & $\begin{array}{l}\text { Gruplar } \\
\text { aras1 }\end{array}$ & 6,101 & 4 & 1,525 & \multirow[t]{3}{*}{1,661} & \multirow[t]{3}{*}{, 158 } & \\
\hline & Gruplar içi & 355,415 & 387 & ,918 & & & \\
\hline & Toplam & 361,517 & 391 & & & & \\
\hline
\end{tabular}

*p<.05

Tablo 10 incelendiğinde engelli çocuk sahibi kadınların yaşadıkları güçlükler çalışma durumuna göre ekonomik ve sosyal güçlük boyutunda anlamlı düzeyde farklılık göstermektedir $(\mathrm{p}<.05)$. Ekonomik güçlük boyutunda anlamlı farklılığın hangi gruplar arasında olduğunu belirlemek amacıyla çoklu karşılaştırma testlerinden Scheffe testi yapılmıştır. Sosyal güçlük boyutuna ilişkin yapılan analizde varyansların homojenliği sağlanmadığı için ikili karşılaştırma testlerinden Games-Howell testi yapılmıştır. Sheffe testi sonuçları incelendiğinde engelli çocuk sahibi kadınların yaşadıkları ekonomik güçlükler açısından çalışmayanlar ve kamu çalışanları arasında anlamlı bir farklılık olduğu ve çalışmayanların lehine olduğu görülmektedir. Başka bir ifade ile çalışmayan engelli çocuk sahibi kadınların yaşadıkları ekonomik güçlük düzeyi kamu çalışanlarına göre daha yüksek düzeydedir. Sosyal güçlük boyutuna ilişkin yapılan GamesHowell Testi sonuçları incelendiğinde emekliler ile kamu çalışanı, özel sektör çalışanı ve çalışmayanlar arasında anlamlı bir farklılık olduğu görülmektedir. Bu bağlamda, emekliler; kamu çalışanı, özel sektör çalışanı ve çalışmayan engelli çocuk sahibi kadınlara göre daha fazla sosyal güçlük yaşamaktadır.

Engelli çocuk sahibi kadınların yaşadıkları güçlüklerin gelir durumlarına göre farklılaşıp farklılaşmadığını belirlemek amacıyla ANOVA testi yapılmıştır. Tablo 11 'de engelli çocuk sahibi kadınların yaşadıkları güçlüklerin gelir durumuna göre ANOVA testi sonuçları sunulmaktadır. 
Tablo 11. Engelli Çocuk Sahibi Kadınların Yaşadıkları Güçlüklerin Gelir Durumuna Göre ANOVA (Tek Yönlü Varyans Analizi) Testi Sonuçları

\begin{tabular}{|c|c|c|c|c|c|c|c|}
\hline Boyutlar & $\begin{array}{l}\text { Varyansın } \\
\text { Kaynağı }\end{array}$ & $\begin{array}{l}\text { Kareler } \\
\text { Toplamı }\end{array}$ & sd & $\begin{array}{l}\text { Kareler } \\
\text { Ortalaması }\end{array}$ & $\mathbf{F}$ & $\mathbf{p}$ & $\begin{array}{l}\text { Anlamlı Fark } \\
\text { (Scheffe) }\end{array}$ \\
\hline \multirow{3}{*}{$\begin{array}{l}\text { Ölçek } \\
\text { (Toplam) }\end{array}$} & Gruplar aras1 & 974 & 4 & ,244 & \multirow[t]{3}{*}{, 591} & \multirow[t]{3}{*}{,669 } & \\
\hline & Gruplar içi & 159,385 & 387 & ,412 & & & \\
\hline & Toplam & 160,359 & 391 & & & & \\
\hline \multirow{3}{*}{$\begin{array}{l}\text { Ekonomik } \\
\text { Güçlük }\end{array}$} & Gruplar aras1 & 9,941 & 4 & 2,485 & \multirow[t]{3}{*}{3,212} & \multirow[t]{3}{*}{,013* } & $0-1000$ છ> 3501-4500 \\
\hline & Gruplar içi & 299,469 & 387 & ,774 & & & \\
\hline & Toplam & 309,409 & 391 & & & & $0-1000 €>4501 €+$ \\
\hline \multirow{3}{*}{ Sosyal Güçlük } & Gruplar aras1 & 2,832 & 4 & ,708 & \multirow[t]{3}{*}{,842 } & \multirow[t]{3}{*}{,499 } & \\
\hline & Gruplar içi & 325,498 & 387 & 841 & & & \\
\hline & Toplam & 328,330 & 391 & & & & \\
\hline \multirow{3}{*}{$\begin{array}{l}\text { Duygusal } \\
\text { Güçlük }\end{array}$} & Gruplar arası & 1,311 & 4 & ,328 & \multirow[t]{3}{*}{ 601 } & \multirow[t]{3}{*}{ 662 } & \\
\hline & Gruplar içi & 211,023 & 387 & ,545 & & & \\
\hline & Toplam & 212,333 & 391 & & & & \\
\hline \multirow{3}{*}{$\begin{array}{l}\text { Fiziksel } \\
\text { Güçlük }\end{array}$} & Gruplar aras1 & 3,960 & 4 & ,990 & \multirow[t]{3}{*}{1,071} & \multirow[t]{3}{*}{,370 } & \\
\hline & Gruplar içi & 357,557 & 387 & ,924 & & & \\
\hline & Toplam & 361,517 & 391 & & & & \\
\hline
\end{tabular}

Tablo 11 incelendiğinde kadınların yaşadıkları güçlükler gelir durumuna göre ekonomik güçlük boyutunda anlamlı düzeyde farklılık göstermektedir $(\mathrm{p}<.05)$. Anlamlı farklılığın hangi gruplar arasında olduğunu belirlemek Scheffe testi yapılmıştır. Tablo 11'de ekonomik güçlük boyutu incelendiğinde 0-1000£ arasında gelire sahip kadınlar ile 3501-4500€ ve 4501€ üstü gelire sahip kadınların yaşadıkları güçlükler anlamlı şekilde farklılaşmaktadır. Bu farklılık 01000€ arasında gelire sahip kadınların lehinedir. Başka bir ifadeyle 0-1000€ arası gelire sahip kadınlar 3501-4500€ arası gelire sahip kadınlardan ve 4501€ üstü gelire sahip kadınlardan anlamlı bir şekilde daha fazla ekonomik güçlük yaşamaktadırlar.

Engelli çocuk sahibi kadınların yaşadıkları güçlüklerin sosyal güvencelerinin bulunması durumuna göre anlamlı şekilde farklılaşıp farklılaşmadığını belirlemek amacıyla bağımsız grup T-testi yapılmıştır. Elde edilen sonuçlar aşağıda Tablo 12'de sunulmuştur.

Tablo 12. Engelli Çocuk Sahibi Kadınların Yaşadıkları Güçlük Puanlarının Sosyal Güvenliği Olma Durumuna Göre Bağımsız Grup T-Testi Sonuçları

\begin{tabular}{|c|c|c|c|c|c|c|}
\hline Boyutlar & Sosyal Güvenlik & $\mathbf{N}$ & $\overline{\mathbf{x}}$ & SS & $\mathbf{t}$ & $\mathbf{p}$ \\
\hline \multirow{2}{*}{ Ölçek (Toplam) } & Evet & 317 & 3,4255 & 61718 & \multirow[t]{2}{*}{,- 200} & \multirow[t]{2}{*}{, 842} \\
\hline & Hayır & 75 & 3,4420 & ,73500 & & \\
\hline \multirow{2}{*}{ Ekonomik Güçlük } & Evet & 317 & 3,5486 & 89140 & \multirow[t]{2}{*}{$-2,426$} & \multirow[t]{2}{*}{,016* } \\
\hline & Hayır & 75 & 3,8240 &, 85200 & & \\
\hline \multirow{2}{*}{ Sosyal Güçlük } & Evet & 317 & 2,7797 & ,92041 & \multirow[t]{2}{*}{, 130} & \multirow[t]{2}{*}{,897 } \\
\hline & Hayır & 75 & 2,7644 & ,90506 & & \\
\hline \multirow{2}{*}{ Duygusal Güçlük } & Evet & 317 & 4,1220 & 67754 & \multirow[t]{2}{*}{2,120} & \multirow[t]{2}{*}{, $035 *$} \\
\hline & Hayır & 75 & 3,9222 & ,93615 & & \\
\hline \multirow{2}{*}{ Fiziksel Güçlük } & Evet & 317 & 3,1186 & ,92041 & \multirow[t]{2}{*}{1,655} & \multirow[t]{2}{*}{,099 } \\
\hline & Hayır & 75 & 2,9147 & 1,11072 & & \\
\hline
\end{tabular}

$* \mathrm{p}<.05$

Tablo 12'ye göre anlamlı farklılık ekonomik güçlük boyutu ve duygusal güçlük boyutunda sosyal güvenceleri olmayan engelli çocuk sahibi kadınların lehinedir. Diğer bir 
ifadeyle sosyal güvenlik sistemi içerisinde yer almayan kadınlar sosyal güvenlik sisteminde yer alan kadınlara göre hem ekonomik hem de duygusal olarak daha yüksek düzeyde güçlük yaşamaktadırlar.

Engelli çocuk sahibi kadınların yaşadıkları güçlüklerin engelli çocuklarının engelli maaşı alma durumlarına göre anlamlı şekilde farklılaşıp farklılaşmadığını belirlemek amacıyla bağımsız grup T-testi yapılmıştır. Elde edilen sonuçlar aşağıda Tablo 13'te sunulmuştur.

Tablo 13. Engelli Çocuk Sahibi Kadınların Yaşadıkları Güçlük Puanlarının Çocuklarının Engelli Maaşı Alma Durumuna Göre Bağımsız Grup T-Testi Sonuçları

\begin{tabular}{|c|c|c|c|c|c|c|}
\hline Boyutlar & $\begin{array}{l}\text { Engelli Aylığı } \\
\text { Alma Durumu }\end{array}$ & $\mathbf{N}$ & $\overline{\mathbf{x}}$ & SS & $\mathbf{t}$ & $\mathbf{p}$ \\
\hline \multirow{2}{*}{ Ölçek (Toplam) } & Evet & 49 & 3,3613 & ,76382 & \multirow{2}{*}{,- 674} & \multirow{2}{*}{,503 } \\
\hline & Hayır & 343 & 3,4383 &, 62150 & & \\
\hline \multirow{2}{*}{ Ekonomik Güçlük } & Evet & 49 & 3,5980 & ,91731 & \multirow[t]{2}{*}{,- 028} & \multirow[t]{2}{*}{,978 } \\
\hline & Hayır & 343 & 3,6017 &, 88691 & & \\
\hline \multirow{2}{*}{ Sosyal Güçlük } & Evet & 49 & 2,7789 & 1,01459 & \multirow[t]{2}{*}{,017 } & \multirow[t]{2}{*}{,986 } \\
\hline & Hayır & 343 & 2,7765 & ,90308 & & \\
\hline \multirow{2}{*}{ Duygusal Güçlük } & Evet & 49 & 4,0850 & ,77886 & \multirow[t]{2}{*}{,013 } & \multirow[t]{2}{*}{,990 } \\
\hline & Hayır & 343 & 4,0836 &, 73193 & & \\
\hline \multirow{2}{*}{ Fiziksel Güçlük } & Evet & 49 & 2,7184 & 1,12021 & \multirow[t]{2}{*}{$-2,836$} & \multirow[t]{2}{*}{, $005 *$} \\
\hline & Hayır & 343 & 3,1312 &, 92714 & & \\
\hline
\end{tabular}

$* \mathrm{p}<.05$

Tablo 13'e bakıldığında ölçek toplamı, ekonomik güçlük boyutu, sosyal güçlük boyutu ve duygusal güçlük boyutunda çocuğu engelli aylığg alanlar ile almayanlar arasında anlamlı bir farklılığın olmadığı görülmektedir. Fiziksel güçlük boyutunda ise anlamlı bir farklılık bulunmakta ve bu farklılık çocuğu engelli maaşı almayan engelli çocuk sahibi kadınların lehinedir. Bir başka ifadeyle çocuğu engelli maaşı almayan kadınlar, çocuğu engelli maaşı alanlara göre daha fazla fiziksel güçlük yaşamaktadır.

Engelli çocuk sahibi kadınların yaşadıkları güçlüklerin evde bakım aylığı alma durumlarına göre anlamlı şekilde farklılaşıp farklılaşmadığını belirlemek amacıyla bağımsız grup T-testi yapılmıştır. Elde edilen sonuçlar aşağıda Tablo 14'te sunulmuştur.

Tablo 14. Engelli Çocuk Sahibi Kadınların Yaşadıkları Güçlük Puanlarının Evde Bakım Aylığı Alma Durumuna Göre Bağımsız Grup T-Testi Sonuçları

\begin{tabular}{|c|c|c|c|c|c|c|c|}
\hline Boyutlar & $\begin{array}{l}\text { Evde } \\
\text { Aylığı } \\
\text { Durumu }\end{array}$ & $\begin{array}{r}\text { Bakım } \\
\text { Alma }\end{array}$ & $\mathbf{N}$ & $\overline{\mathbf{x}}$ & SS & $\mathbf{t}$ & $\mathbf{p}$ \\
\hline \multirow{2}{*}{ Ölçek (Toplam) } & Evet & & 184 & 3,4648 & ,63665 & 1,050 & ,294 \\
\hline & Hayır & & 208 & 3,3967 &, 64356 & & \\
\hline \multirow{2}{*}{ Ekonomik Güçlük } & Evet & & 184 & 3,7033 & ,82673 & 2,145 & ,033* \\
\hline & Hayır & & 208 & 3,5111 & ,93438 & & \\
\hline \multirow{2}{*}{ Sosyal Güçlük } & Evet & & 184 & 2,7736 & ,97699 &,- 065 & ,948 \\
\hline & Hayır & & 208 & 2,7796 & ,86155 & & \\
\hline \multirow{2}{*}{ Duygusal Güçlük } & Evet & & 184 & 4,1051 &, 71722 & ,538 & ,591 \\
\hline & Hayır & & 208 & 4,0649 &, 75514 & & \\
\hline \multirow{2}{*}{ Fiziksel Güçlük } & Evet & & 184 & 3,0489 & ,98046 &,- 594 & ,553 \\
\hline & Hayır & & 208 & 3,1067 & ,94606 & & \\
\hline
\end{tabular}

*p<.05 
Tablo 14'e göre engelli çocuk sahibi kadınların yaşadıkları güçlüklerin evde bakım aylığ́ alma durumuna göre ölçek toplamı, sosyal güçlük boyutu, duygusal güçlük boyutu ve fiziksel güçlük boyutunda anlamlı bir farklılık yoktur. Engelli çocuk sahibi kadınların yaşadıkları ekonomik güçlükler ile evde bakım aylığı alma durumları arasında anlamlı bir farklılığın olduğu ve bu farklılığın evde bakım aylığı alan kadınların lehine olduğu görülmektedir. Başka bir deyişle evde bakım aylığı alan engelli çocuk sahibi kadınlar evde bakım aylığı almayan kadınlara göre daha yüksek düzeyde ekonomik güçlük yaşamaktadır.

Engelli çocuk sahibi kadınların yaşadıkları güçlüklerin engelli çocuğun yaşına göre farklılaşma durumunu incelemek amacıyla ANOVA testi yapılmıştır. Tablo 15'te engelli çocuk sahibi kadınların yaşadıkları güçlüklerin engelli çocuklarının yaşlarına göre ANOVA testi sonuçları sunulmaktadır.

Tablo 15. Engelli Çocuk Sahibi Kadınların Yaşadıkları Güçlüklerin Engelli Çocuğun Yaşına Göre ANOVA (Tek Yönlü Varyans Analizi) Testi Sonuçları

\begin{tabular}{|c|c|c|c|c|c|c|c|}
\hline Boyutlar & $\begin{array}{l}\text { Varyansın } \\
\text { Kaynağı } \\
\end{array}$ & $\begin{array}{l}\text { Kareler } \\
\text { Toplamı }\end{array}$ & sd & $\begin{array}{l}\text { Kareler } \\
\text { Ortalaması }\end{array}$ & $\mathbf{F}$ & $\mathbf{p}$ & $\begin{array}{l}\text { Anlamlı Fark } \\
\text { (Scheffe) }\end{array}$ \\
\hline \multirow{3}{*}{$\begin{array}{l}\text { Ölçek } \\
\text { (Toplam) }\end{array}$} & $\begin{array}{l}\text { Gruplar } \\
\text { aras1 }\end{array}$ & 2,748 & 4 & ,687 & \multirow[t]{3}{*}{1,687} & \multirow[t]{3}{*}{,152 } & \\
\hline & Gruplar içi & 157,611 & 387 & ,407 & & & \\
\hline & Toplam & 160,359 & 391 & & & & \\
\hline \multirow{4}{*}{$\begin{array}{l}\text { Ekonomik } \\
\text { Güçlük }\end{array}$} & Gruplar & 5,811 & 4 & 1,453 & \multirow[t]{4}{*}{1,852} & \multirow[t]{4}{*}{,118 } & \\
\hline & aras1 & & & & & & \\
\hline & Gruplar içi & 303,598 & 387 & ,784 & & & \\
\hline & Toplam & 309,409 & 391 & & & & \\
\hline \multirow{4}{*}{ Sosyal Güçlük } & Gruplar & 19,791 & 4 & 4,948 & \multirow[t]{4}{*}{6,206} & \multirow[t]{4}{*}{, $000 *$} & $18+$ Yaş > 0-2 Yaş \\
\hline & $\operatorname{aras} 1$ & & & & & & $18+\mathrm{Yaş}>3-6 \mathrm{Yaş}$ \\
\hline & Gruplar içi & 308,539 & 387 & ,797 & & & \\
\hline & Toplam & 328,330 & 391 & & & & \\
\hline \multirow{3}{*}{$\begin{array}{l}\text { Duygusal } \\
\text { Güçlük }\end{array}$} & $\begin{array}{l}\text { Gruplar } \\
\text { aras1 }\end{array}$ & 2,140 & 4 & ,535 & \multirow[t]{3}{*}{,985 } & \multirow[t]{3}{*}{415} & \\
\hline & Gruplar içi & 210,193 & 387 &, 543 & & & \\
\hline & Toplam & 212,333 & 391 & & & & \\
\hline \multirow{3}{*}{$\begin{array}{l}\text { Fiziksel } \\
\text { Güçlük }\end{array}$} & $\begin{array}{l}\text { Gruplar } \\
\text { aras1 }\end{array}$ & 15,322 & 4 & 3,831 & \multirow[t]{3}{*}{4,282} & \multirow[t]{3}{*}{, $002 *$} & \multirow[t]{3}{*}{$18+$ Yaş $>0-2$ Yaş } \\
\hline & Gruplar içi & 346,194 & 387 & ,895 & & & \\
\hline & Toplam & 361,517 & 391 & & & & \\
\hline
\end{tabular}

*p<.05

Sosyal güçlük boyutu ve fiziksel güçlük boyutunda gruplar arasında anlamlı bir farklılık bulunduğu görülmektedir. Hangi gruplar arasında olduğunu belirlemek amaciyla ikili karşılaştırma testlerinden Scheffe testi yapılmıştır. Sosyal güçlük boyutundaki anlamlı farklılık incelendiğinde; 0-2 yaş arası ve 3-6 yaş arası engelli çocuğu olan grup ile 18 yaş üstü engelli çocuğu olan grup arasında anlamlı bir farklılık olduğu görülmektedir. Bu bağlamda 18 yaş üstü engelli çocuğu bulunan kadınlar, 0-2 yaş ve 3-6 yaş arası engelli çocuğu bulunan kadınlara göre sosyal güçlük boyutunda daha yüksek güçlük yaşamaktadır. 
Fiziksel güçlük boyutundaki anlamlı farklılık incelendiğinde 0-2 yaş grubunda engelli çocuğu olan kadınlar ile 18 yaş üstü engelli çocuğu olan kadınlar arasında anlamlı bir fark olduğu görülmektedir. Fiziksel güçlük boyutundaki bu anlamlı farklılık 18 yaş üstü engelli çocuğu olan kadınların lehinedir. Bir başka deyişle 18 yaş üstü engelli çocuğu bulunan kadınların yaşadıkları fiziksel güçlük 0-2 yaş aralığında engelli çocuk sahibi kadınlara göre daha yüksek düzeydedir.

Engelli çocuk sahibi kadınların yaşadıkları güçlüklerin engelli çocuğun tıbbi tanısına göre farklılaşma durumunu belirlemek amacıyla ANOVA testi yapılmıştır. Aşağıda Tablo 16 'da engelli çocuk sahibi kadınların yaşadıkları güçlüklerin engelli çocuklarının tıbbi tanısına göre ANOVA testi sonuçları sunulmaktadır.

Tablo 16. Engelli Çocuk Sahibi Kadınların Yaşadıkları Güçlüklerin Engelli Çocuğun Tıbbi Tanısına Göre ANOVA (Tek Yönlü Varyans Analizi) Testi Sonuçları

\begin{tabular}{|c|c|c|c|c|c|c|c|}
\hline Boyutlar & $\begin{array}{l}\text { Varyansın } \\
\text { Kaynağı }\end{array}$ & $\begin{array}{l}\text { Kareler } \\
\text { Toplamı }\end{array}$ & sd & $\begin{array}{l}\text { Kareler } \\
\text { Ortalaması }\end{array}$ & $\mathbf{F}$ & $\mathbf{p}$ & $\begin{array}{l}\text { Anlamlı Fark } \\
\text { (Scheffe ve Games-Howell) }\end{array}$ \\
\hline $\begin{array}{l}\text { Ölçek } \\
\text { (Toplam) }\end{array}$ & $\begin{array}{l}\text { Gruplar } \\
\text { arasi } \\
\text { Gruplar içi } \\
\text { Toplam }\end{array}$ & $\begin{array}{l}151,379 \\
160,359\end{array}$ & $\begin{array}{l}385 \\
391\end{array}$ & 1,497 & 3,806 & ,001* & $\begin{array}{l}\text { Otizm }>\text { Görme Engeli } \\
\text { Çoklu Engellilik }>\text { Görme } \\
\text { Engeli } \\
\text { Çoklu Engellilik>İşitme Engeli }\end{array}$ \\
\hline $\begin{array}{l}\text { Ekonomik } \\
\text { Güçlük }\end{array}$ & $\begin{array}{l}\text { Gruplar } \\
\text { arasi } \\
\text { Gruplar içi } \\
\text { Toplam }\end{array}$ & $\begin{array}{l}7,254 \\
302,155 \\
309,409\end{array}$ & $\begin{array}{l}6 \\
385 \\
391\end{array}$ & $\begin{array}{l}1,209 \\
, 785\end{array}$ & 1,541 & ,164 & \\
\hline $\begin{array}{l}\text { Sosyal } \\
\text { Güçlük }\end{array}$ & $\begin{array}{l}\text { Gruplar } \\
\text { arasi } \\
\text { Gruplar içi } \\
\text { Toplam }\end{array}$ & $\begin{array}{l}36,408 \\
291,922 \\
328,330\end{array}$ & $\begin{array}{l}385 \\
391\end{array}$ & $\begin{array}{l}6,068 \\
, 758\end{array}$ & 8,003 & ,000* & $\begin{array}{l}\text { Zihinsel Engel }>\text { Bedensel } \\
\text { Engel } \\
\text { Zihinsel Engel }>\text { Görme Engeli } \\
\text { Zihinsel Engel }>\text { İşitme Engeli } \\
\text { Otizm }>\text { Bedensel Engel } \\
\text { Otizm }>\text { Görme Engeli } \\
\text { Otizm }>\text { İşitme Engeli } \\
\text { Çoklu Engellilik }>\text { İşitme Engeli }\end{array}$ \\
\hline $\begin{array}{l}\text { Duygusal } \\
\text { Güçlük }\end{array}$ & $\begin{array}{l}\text { Gruplar } \\
\text { arasi } \\
\text { Gruplar içi } \\
\text { Toplam }\end{array}$ & $\begin{array}{l}199,784 \\
212,333\end{array}$ & $\begin{array}{l}385 \\
391\end{array}$ & 2,092 & 4,031 & ,001* & $\begin{array}{l}\text { Bedensel Engel }>\text { İşitme Engeli } \\
\text { Otizm }>\text { İşitme Engeli } \\
\text { Çoklu Engellilik }>\text { İşitme Engeli }\end{array}$ \\
\hline $\begin{array}{l}\text { Fiziksel } \\
\text { Güçlük }\end{array}$ & $\begin{array}{l}\text { Gruplar } \\
\text { arasi } \\
\text { Gruplar içi } \\
\text { Toplam }\end{array}$ & $\begin{array}{l}326,110 \\
361,517\end{array}$ & $\begin{array}{l}385 \\
391\end{array}$ & $\begin{array}{l}5,901 \\
, 847\end{array}$ & 6,967 & ,000* & $\begin{array}{l}\text { Zihinsel Engel }>\text { Görme Engeli } \\
\text { Zihinsel Engel }>\text { İşitme Engeli } \\
\text { Bedensel Engel }>\text { İşitme Engeli } \\
\text { Bedensel Engel }>\text { İşitme Engeli } \\
\text { Otizm }>\text { Görme Engeli } \\
\text { Otizm }>\text { İşitme Engeli } \\
\text { Çoklu Engellilik }>\text { Görme } \\
\text { Engeli } \\
\text { Çoklu Engellilik }>\text { İşitme Engeli }\end{array}$ \\
\hline
\end{tabular}

${ }^{*} \mathrm{p}<.05$

Tablo 16'ya bakıldığında engelli çocuk sahibi kadınların yaşadıkları güçlükler, engelli çocuklarının tıbbi tanısına göre ölçek toplamı, sosyal güçlük boyutu, duygusal güçlük boyutu ve fiziki güçlük boyutunda anlamlı bir şekilde farklılık göstermektedir $(\mathrm{p}<.05)$. Ölçek toplamı ve fiziksel güçlük boyutunda varyansın homojen dağılım göstermesinden dolayı Scheffe testi, 
sosyal güçlük ve duygusal güçlük boyutunda ise varyansın homojen dağılım göstermemesi sebebiyle Games Howell testi uygulanmıştır.

İkili karşılaştırma testlerinden ölçek toplamına yönelik yapılan scheffe testi sonucuna göre otizmli çocuk sahibi kadınların yaşadıkları güçlük düzeyi ile görme engelli çocuk sahibi kadınların yaşadıkları güçlük düzeyleri arasında anlamlı bir farklılık vardır. Otizmli çocuk sahibi kadınlar, görme engelli çocuk sahibi kadınlara nazaran daha yüksek düzeyde güçlük yaşamaktadırlar. Ölçek toplamı bakımından diğer bir anlamlı farklılık, çoklu engeli olan çocuk sahibi kadınlar ile görme engelli ve işitme engelli çocuk sahibi kadınlar arasındadır. Çoklu engelli çocuk sahibi kadınların yaşadıkları güçlük düzeyi; görme engelli ve işitme engelli çocuk sahibi kadınların yaşadıkları güçlük düzeyine göre daha yüksek düzeydedir.

Sosyal güçlük boyutundaki ikili karşılaştırma testlerinden Games Howell testi sonuçları incelendiğinde zihinsel engelli çocuğa sahip kadınların yaşadıkları güçlükler ile bedensel engelli, görme engelli ve işitme engelli çocuğa sahip kadınların yaşadıkları güçlükler arasında anlamlı bir farklılık görülmektedir. Zihinsel engelli çocuk sahibi kadınların yaşadıkları sosyal güçlük düzeyi bedensel engelli, görme engelli ve işitme engelli çocuk sahibi kadınların yaşadıkları sosyal güçlük düzeyinden daha yüksektir. Sosyal güçlük boyutundaki bir diğer anlamlı farklılık ise otizmli çocuk sahibi kadınlar ile bedensel engelli, görme engelli ve işitme engelli çocuk sahibi kadınlar arasındadır. Otizmli çocuk sahibi kadınların yaşadıkları sosyal güçlük düzeyinin bedensel engelli, görme engelli ve işitme engelli çocuk sahibi kadınların yaşadıkları sosyal güçlük düzeyinden daha yüksek olduğu anlaşılmaktadır. Yine sosyal güçlük boyutunda bulunan diğer bir anlamlı farklılık çoklu engelli çocuk sahibi kadınlar ile işitme engelli çocuk sahibi kadınlar arasındadır. Çoklu engelli çocuk sahibi kadınların işitme engelli çocuk sahibi kadınlara nazaran daha yüksek sosyal güçlük yaşadığı anlamına gelmektedir.

Duygusal güçlük boyutunda gruplar arası anlamlı farklılık durumu incelendiğinde bedensel engelli çocuk sahibi kadınlar ile işitme engelli çocuk sahibi kadınlar arasında anlamlı bir farklılık bulunmaktadır ve bu farklılık bedensel engelli çocuk sahibi kadınların lehinedir. Diğer bir ifadeyle bedensel engelli çocuk sahibi kadınlar işitme engelli çocuk sahibi kadınlara göre anlamlı bir şekilde daha yüksek güçlük yaşamaktadırlar. Tablo 16'ya göre otizmli çocuk sahibi kadınlar ile işitme engelli çocuk sahibi kadınların yaşadıkları duygusal güçlükler arasında anlamlı bir farklılık vardır. Otizmli çocuk sahibi kadınların yaşadıkları duygusal güçlük düzeyi işitme engelli çocuk sahibi kadınlara göre anlamlı bir şekilde daha yüksektir. Duygusal güçlük boyutunda görülen bir diğer anlamlı farklılık ise çoklu engelli çocuk sahibi kadınlar ile işitme engelli çocuk sahibi kadınlar arasındadır ve çoklu engelli çocuk sahibi 
kadınlar işitme engelli çocuk sahibi kadınlara göre anlamlı bir şekilde daha yoğun duygusal güçlük yaşamaktadırlar.

Fiziksel güçlük boyutunda zihinsel engelli çocuk sahibi kadınlar ile görme engelli ve işitme engelli çocuk sahibi kadınlar arasında anlamlı bir farklılık bulunmaktadır. Zihinsel engelli çocuk sahibi kadınlar görme engelli ve işitme engelli çocuk sahibi kadınlara nazaran daha yüksek fiziksel güçlük yaşamaktadır. Fiziksel güçlük boyutunda görülen bir diğer anlamlı farklılık bedensel engelli çocuk sahibi kadınlar ile görme engelli ve işitme engelli çocuk sahibi kadınlar arasındadır. Buna göre bedensel engelli çocuk sahibi kadınlar görme engelli ve işitme engelli çocuk sahibi kadınlara göre daha yüksek düzeyde fiziksel güçlük yaşamaktadır. Bir diğer anlamlı farklılık, otizmli çocuk sahibi kadınlar ile görme engelli ve işitme engelli çocuk sahibi kadınlar arasındadır. Bu durum otizmli çocuk sahibi kadınların görme engelli ve işitme engelli çocuk sahibi kadınlara göre fiziksel güçlük boyutunda daha yüksek güçlük yaşadıkları anlamına gelmektedir. Fiziksel güçlük boyutunda yer alan bir diğer anlamlı farklılık ise çoklu engelli çocuk sahibi kadınlar ile görme engelli ve işitme engelli çocuk sahibi kadınlar arasındadır. Çoklu engelli çocuk sahibi kadınlar görme engelli ve işitme engelli çocuk sahibi kadınlara göre daha yüksek düzeyde fiziksel güçlük yaşamaktadır.

\section{Sonuç}

Araştırmanın güçlük düzeylerinden elde edilen bulgulara göre engelli çocuk sahibi kadınların genel olarak yüksek düzeyde $(\bar{x}=3,428)$ güçlük yaşadıkları sonucuna ulaşılmıştır. Ekonomik güçlük boyutu incelendiğinde; çocuklarının engelli olmasının aile bütçelerini zorlayan ve masraflarını artıran bir durum olduğu ve engelli çocuklarının sağlık giderlerini, eğitim harcamalarını ve bakıcı masraflarını karşılamakta yüksek düzeyde güçlük yaşadıkları görülmektedir. Engelli çocuk sahibi kadınlar, engelli çocuklarının yüksek masrafları nedeniyle sosyal harcamalarını kısmakta ve kendi özel ihtiyaçlarını karşılamakta zorlanmaktadırlar. Ayrıca kadınlar, engelli çocukları için devlet tarafından sağlan desteklerin yetersiz olduğu görüşüne çok yüksek düzeyde katılım göstermektedirler. Bu bağlamda engelli çocuk sahibi kadınların yüksek düzeyde $(\overline{\mathrm{x}}=3,601)$ ekonomik güçlük yaşadıkları sonucuna ulaşılmıştır. Engelli çocuk sahibi kadınların yaşadıkları sosyal güçlükler incelendiğinde; kadınların yüksek düzeyde katılımıyla, diğer insanların onlara acıyarak baktıklarını düşündükleri görülmektedir. Sosyal güçlük boyutunda elde edilen bulgulara göre kadınların orta düzeyde $(\bar{x}=2.776)$ güçlük yaşadıkları sonucuna ulaşılmıştır. Engelli çocuk sahibi kadınların duygusal güçlükleri incelendiğinde; çocuklarının geleceğinden ve kendileri öldükten sonra çocuklarına kimin bakacağı konusunda çok yüksek düzeyde endişe duydukları görülmektedir. Ayrıca yüksek 
düzeyde; çocuklarının yaşıtlarının gerisinde olmasından dolayı üzüldükleri, diğer insanların meraklı gözlerle bakmasından hoşlanmadıkları ve çocuklarının engelliliğinden dolayı sıklıkla ağladıkları şeklinde duygusal güçlükler yaşamaktadırlar. Genel olarak duygusal güçlük boyutunda yüksek düzeyde $(\bar{x}=4,083)$ güçlük yaşandığı sonucuna ulaşılmıştır. Engelli çocuk sahibi kadınların yaşadıkları fiziksel güçlükler incelendiğinde; çocuklarının bakımları, kadınların yüksek düzeyde güçlük yaşamalarına sebep olmaktadır. Genel olarak fiziksel güçlük boyutunda engelli çocuk sahibi kadınların orta düzeyde $(\bar{x}=3,079)$ güçlük yaşadığı sonucu elde edilmiştir. Araştırmadan elde edilen bulgular incelendiğinde yoğunluk sırasına göre; duygusal, ekonomik, fiziksel ve sosyal boyutlarda güçlük yaşanmaktadır.

Engelli çocuk sahibi kadınların yaşadıkları güçlüklerin yaşlarına göre ölçek boyutlarından sosyal güçlük ve fiziksel güçlük boyutunda anlamlı bir farklılığın olduğu görülmüştür. Buna göre 36- 50 yaş arası kadınlar 18- 35 yaş arası kadınlara göre daha fazla sosyal güçlük yaşamaktadırlar. Fiziksel güçlük açısından ise 18- 35 yaş arası kadınlar ile 3650 yaş arası kadınların yaşadıkları güçlükler arasında anlamlı bir farklılık vardır. Buna göre 3650 yaş arası kadınlar 18- 35 yaş arası kadınlara göre fiziksel olarak daha fazla güçlük yaşamaktadırlar. Bu bağlamda engelli çocuk sahibi kadınların yaşı arttıkça fiziksel ve sosyal güçlüğün yoğunlaştığı sonucuna ulaşılmıştır. Engelli çocuk sahibi kadınların yaşadıkları güçlüklerin medeni durumlarına göre anlamlı bir farklılık göstermediği sonucuna ulaşılmıştır. Eğitim durumları açısından engelli çocuk sahibi kadınların yaşadıkları güçlükler incelendiğinde duygusal güçlük boyutunda anlamlı bir farklılığın olduğu görülmüştür. Üniversite mezunu kadınların yaşadıkları duygusal güçlükler ortaokul mezunu kadınlara göre daha yüksek düzeydedir. Eğitim seviyesinin yükselmesi duygusal açıdan yaşanılan güçlüğü arttırdığı söylenebilir.

Engelli çocuk sahibi kadınların yaşadıkları güçlüklerin çalışma durumlarına göre ekonomik ve sosyal güçlük boyutunda anlamlı bir farklılık gösterdiği görülmüştür. Ekonomik güçlük boyutunda anlamlı farklılık çalışmayan kadınlar ile kamu çalışanı kadınlar arasındadır. Buna göre çalışmayan kadınlar, kamu çalışanı kadınlara göre daha yüksek düzeyde ekonomik güçlük yaşamaktadırlar. Bu durum düzenli gelir sahibi olmanın ekonomik güçlüğü hafifletici etkisinden kaynaklanmaktadır. Çalışma durumuna göre bir diğer anlamlı farklılık ise sosyal güçlük boyutundadır. Buna göre emekli kadınlar; kamu çalışanı, özel sektör çalışanı ve çalışmayan engelli çocuk sahibi kadınlara göre daha fazla sosyal güçlük yaşamaktadırlar. Emekli kadınların daha yoğun sosyal güçlük yaşamaları, boş zamanlarının çok ve daha yaşlı olmalarından kaynaklandığı şeklinde açıklanabilir. Engelli çocuk sahibi kadınların gelir durumuna göre ekonomik güçlük boyutunda anlamlı bir farklılık olduğu görülmüştür. Geliri 0- 
1000€ olan kadınlar, 3501-4500€ ve 4501€ üstü gelire sahip kadınlara göre daha yüksek düzeyde ekonomik güçlük yaşamaktadırlar. $\mathrm{Bu}$ sonuca göre gelirin ekonomik güçlügü hafifletici etkisi doğrulanmaktadır.

Engelli çocuk sahibi kadınların sosyal güvenlik durumları dikkate alınarak yaşadıkları güçlükler incelendiğinde; sosyal güvenliği olmayan kadınların ekonomik açıdan daha fazla güçlük yaşadıkları anlamlı bir şekilde farklılaşmaktadır. Engelli çocuğun engelli maaşı alması durumuna göre kadınların yaşadıkları güçlükler fiziksel güçlük boyutunda anlamlı farklılık göstermiştir. Buna göre engelli maaşı almayan çocuk sahibi kadınlar engelli maaşı alan çocuk sahibi kadınlara göre fiziksel olarak daha yoğun güçlük yaşamaktadırlar. Evde bakım aylığı alma durumu açısından kadınların yaşadıkları güçlükler incelendiğinde ekonomik boyutta anlamlı bir farklılık görülmektedir. Evde bakım aylığı alanlar almayan kadınlara nazaran daha fazla güçlük çekmektedirler. Bu durum evde bakım aylığı alma koşulları dikkate alınarak değerlendirildiğinde amacına uygun olduğunu göstermektedir. Evde bakım aylığı alan kadınların yaşadıkları güçlüklerin yoğun olması gerçekten de ekonomik yetersizliği olan kadınlara yönelik uygulandığı anlamına gelmektedir. Diğer açıdan ise, evde bakım aylığının ekonomik refahı sağlamaktaki etkisinin yetersiz olduğu ifade edilebilir

Kadınların yaşadıkları güçlükler engelli çocuğun yaşına göre sosyal ve fiziksel güçlük boyutunda anlamlı farklılık göstermektedir. Sosyal güçlük bağlamında; 18 yaş üstü çocuğu olan kadınlar 0-2 yaş ve 3-6 yaş arasında çocuğu olan kadınlara göre daha fazla sosyal güçlük yaşamaktadır. Bu durum engelli çocuğun yaşının artmasının, yaşanılan sosyal güçlüklerin daha yoğun yaşanmasına neden olduğunu göstermektedir. Ayrıca 18 yaş üstü çocuğu olan kadınların 0-2 yaş çocuğu olan kadınlara göre daha fazla fiziksel güçlük yaşadıkları sonucuna ulaşılmıştır. Yaşın artmasıyla birlikte çocuk fiziksel olarak da gelişim göstermektedir. Bu durum bakım veren kadının fiziksel olarak daha fazla güçlük çekmesine sebep olmaktadır.

Engelli çocuk sahibi kadınların yaşadıkları güçlükler engelli çocuğun tıbbi tanısına göre incelendiğinde; ölçek toplamı, sosyal, duygusal ve fiziksel güçlük boyutlarında anlamlı farklılığın olduğu görülmektedir. Otizmli çocuk sahibi kadınlar görme engelli çocuk sahibi kadınlara göre; çoklu engeli olan çocuk sahibi kadınlar, görme ve işitme engeli olan çocuk sahibi kadınlara göre ölçek genelinde daha yoğun güçlük yaşamaktadırlar. Sosyal güçlük boyutunda zihinsel engelli çocuk sahibi kadınlar; bedensel, görme ve işitme engelli çocuk sahibi kadınlara göre daha yüksek düzeyde güçlük yaşamaktadırlar. Ayrıca otizmli çocuk sahibi kadınlar; bedensel, görme ve işitme engelli çocuk sahibi kadınlara göre daha yüksek sosyal güçlük yaşamaktadırlar. Son olarak çoklu engelli çocuk sahibi kadınlar işitme engelli çocuk sahibi kadınlara göre sosyal anlamda daha yoğun güçlük yaşamaktadırlar. Bu durum otizm, 
zihinsel engellilik ve çoklu engelliliğin toplumsal olarak daha zor kabul edilebilir ve daha yoğun ayrımcılığa maruz kalan gruplar olması bilgisiyle örtüşmektedir. Genel olarak otizmli ve zihinsel engelli çocuklar, yüksek düzeyde sosyal güçlük yaşamaktadır bu durumun ebeveynlere de sosyal dışlanma şeklinde yansıdığı söylenebilir. Duygusal güçlük boyutunda ise bedensel, otizmli ve çoklu engelli çocuk sahibi kadınlar işitme engelli çocuk sahibi kadınlara göre anlamlı bir şekilde daha yüksek düzeyde duygusal güçlük yaşamaktadırlar. Fiziksel güçlük boyutunda zihinsel, bedensel, otizm ve çoklu engelli çocuk sahibi kadınlar ile görme ve işitme engelli çocuk sahibi kadınlar arasında anlamlı bir farklılık bulunmaktadır. Bu anlamlı farklılığa göre zihinsel, bedensel, otizm ve çoklu engelli çocuk sahibi kadınlar görme ve işitme engelli çocuk sahibi kadınlara göre fiziksel olarak anlamlı bir şekilde daha yoğun güçlük yaşamaktadırlar. Bu sonuçlara göre bedensel, zihinsel, otizm ve çoklu engelli bireylerin bakım yükünün görme ve işitme engelli bireylere göre daha güç olduğu ifade edilebilir.

\section{Kaynakça}

Akandere, M., Acar, M. ve Baştuğ, G. (2009). Zihinsel ve fiziksel engelli çocuğa sahip anne ve babaların yaşam doyumu ve umutsuzluk düzeylerinin incelenmesi. Selçuk Üniversitesi Sosyal Bilimler Enstitüsü Dergisi, 22, 23-32.

Akça, F. ve Özyürek, A. (2019). Zihinsel yetersizlikten etkilenmiş ve normal gelişen çocuğa sahip ebeveynlerin sıkıntıyı tolere etme, depresyon, anksiyete ve stres düzeyleri. Journal of History Culture and Art Research, 8(1), 347-361.

Aysan, F. ve Özben, Ş. (2007). Engelli çocuğu olan anne babaların yaşam kalitelerine ilişkin değişkenlerin incelenmesi. Dokuz Eylül Üniversitesi Buca Eğitim Fakültesi Dergisi, 22, $1-6$.

Başol, G. (2019). Araştırmacılar için istatistik. Ankara: Pegem Akademi

Busch, S. H. and Barry, C. L. (2007). Mental health disorders in childhood: Assessing the burden on families. Health Affairs, 26(4), 1088-1095.

Büyüköztürk, Ş., Çakmak, E. K., Akgün, Ö. E., Karadeniz, Ş., ve Demirel, F. (2014). Bilimsel araştırma yöntemleri. Ankara: Pegem Akademi.

Carlson, J. M. and Miller, P. A. (2017). Family burden, child disability, and the adjustment of mothers caring for children with epilepsy: role of social support and coping. Epilepsy \& Behavior, 68, 168-173.

Demirbilek, M. (2013). Zihinsel engelli bireylerin ve ailelerinin gereksinimleri. Turkish Journal of Family Medicine and Primary Care, 7(3), 58-64.

Deveci, M. ve Ahmetoğlu, E. (2018). Zihin engelli çocuğu olan ailelerin algıladıkları sosyal destek düzeyinin incelenmesi. Balkan ve Yakın Doğu Sosyal Bilimler Dergisi, 4(2), 123 131.

Erkuş, A. (2005). Bilimsel araştırma sarmalı. Ankara: Seçkin Yayıncılık

Fairthorne, J., de Klerk, N. and Leonard, H. (2016). Brief report: Burden of care in mothers of children with autism spectrum disorder or intellectual disability. Journal of Autism and Developmental Disorders, 46(3), 1103-1109.

George, D. and Mallery, M. (2010). SPSS for Windows Step by Step: A Simple Guide and Reference, 17.0 update (10a ed.) Boston: Pearson. 
Ghosh, S. and Parish, S. (2013). Prevalence and economic well-being of families raising multiple children with disabilities. Children and Youth Services Review, 35(9), 14311439.

Gobrial, E. (2018). The lived experiences of mothers of children with the autism spectrum disorders in Egypt. Social sciences, 7(133), 1-11.

Green, S., Davis, C., Karshmer, E., Marsh, P. and Straight, B. (2005). Living stigma: the impact of labeling, stereotyping, separation, status loss, and discrimination in the lives of individuals with disabilities and their families. Sociological Inquiry, 75(2), 197-215.

Güler, M. ve Çapri, B. (2019). Grup rehberliği programının engelli çocuğa sahip çalışan annelerin mesleki tükenmişlik, işle bütünleşme ve eş tükenmişliği düzeyine etkisi. Mersin Üniversitesi Ë̆itim Fakültesi Dergisi, 15(1), 28-46.

Hair, J. F., Black, W. C., Babin, B. J., Anderson, R. E. and Tatham, R. L. (2013). Multivariate Data Analysis: Pearson Education Limited.

Jahan, S., Araf, K., Gozal, D., Griffiths, M. D. and Mamun, M. A. (2020). Depression and suicidal behaviors among Bangladeshi mothers of children with autistic spectrum disorder: a comparative study. Asian journal of psychiatry. 1-7.

Küçük, E. E. and Alemdar, D. K. (2018). Life satisfaction and psychological status of mothers with disabled children: a descriptive study. Community Mental Health Journal, 54(1), 102-106.

Lalvani, P. (2008). Mothers of children with Down syndrome: Constructing the sociocultural meaning of disability. Intellectual and Developmental Disabilities, 46(6), 436-445.

Lee, M. H., Matthews, A. K. and Park, C. (2019). Determinants of health-related quality of life among mothers of children with cerebral palsy. Journal of Pediatric Nursing, 44, 1-8.

Meşe, İ. (2013). Engellenmiş annelik: zihinsel engelli çocuklarin anneleri. International Periodical For the Languages, Literature and History of Turkish or Turkic 8(12), 841858.

Oti-Boadi, M. (2017). Exploring the lived experiences of mothers of children with intellectual disability in Ghana. Sage Open, 7(4), 1-12.

Ören B. ve Aydın, R. Engelli çocuğa sahip ebeveynlerde bakım veren yükü ve depresyon durumlarının incelenmesi. Celal Bayar Üniversitesi Săglı Bilimleri Enstitüsü Dergisi, 7(3), 302-309.

Pepperell, T. A., Paynter, J. and Gilmore, L. (2018). Social support and coping strategies of parents raising a child with autism spectrum disorder. Early Child Development and Care, 188(10), 1392-1404.

Porterfield, S. L. (2002). Work choices of mothers in families with children with disabilities. Journal of Marriage and Family, 64(4), 972-981.

Sönmez, V. ve Alacapınar, F. G. (2011). Örneklendirilmiş bilimsel araştırma yöntemleri. Ankara: Anı Yayıncilık.

Tabachnick B.G. and Fidell, L.S. (2013). Fidell Using Multivariate Statistics (sixth ed.)Pearson, Boston.

Xiong, N., Yang, L., Yu, Y., Hou, J., Li, J., Li, Y., Liu, H., Zhang, Y. and Jiao, Z. (2011). Investigation of raising burden of children with autism, physical disability and mental disability in China. Research in developmental disabilities, 32(1), 306-311.

Yıldırım- Sarı, H. (2007). Zihinsel engelli çocuğu olan ailelerde aile yüklenmesi. Cumhuriyet Üniversitesi Hemşirelik Yüksekokul Dergisi, 11(2), 1-7.

Yüksel, A. (2021). Dezavantajlılı̆̆ın bir adım ötesi: engelli çocuk sahibi kadınların yaşadıkları güçlüklerin incelenmesi ve sosyal politika önerileri. , (Yayımlanmamış Doktora Tezi), Gazi Üniversitesi/Sosyal Bilimler Enstitüsü, Ankara. 